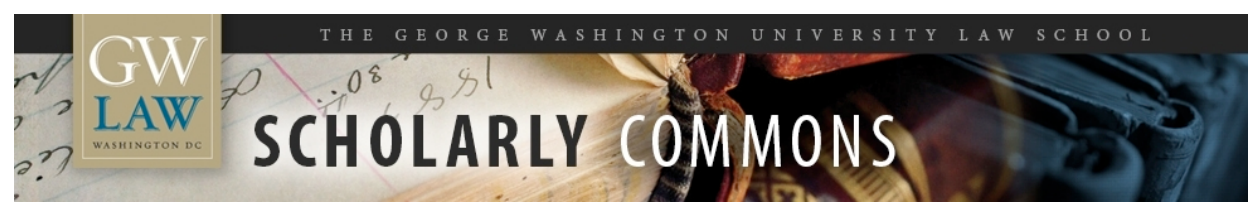

\title{
The Centrality of Military Procurement: Explaining the Exceptionalist Character of United States Federal Public Procurement Law
}

Joshua I. Schwartz

jschwar@law.gwu.edu

Follow this and additional works at: https://scholarship.law.gwu.edu/faculty_publications

Part of the Law Commons

\section{Recommended Citation}

Schwartz, Joshua I., "The Centrality of Military Procurement: Explaining the Exceptionalist Character of United States Federal Public Procurement Law" (2004). GW Law Faculty Publications \& Other Works. 1077.

https://scholarship.law.gwu.edu/faculty_publications/1077

This Article is brought to you for free and open access by the Faculty Scholarship at Scholarly Commons. It has been accepted for inclusion in GW Law Faculty Publications \& Other Works by an authorized administrator of Scholarly Commons. For more information, please contact spagel@law.gwu.edu. 


\title{
The Centrality of Military Procurement: Explaining the Exceptionalist Character of United States Federal Public Procurement Law
}

\author{
Joshua I. Schwartz*
}

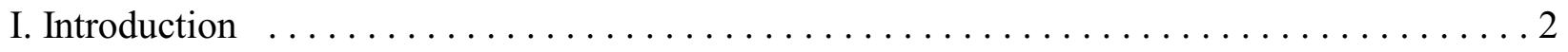

II. What is Exceptionalism? Where and When Does it Occur? . . . . . . . . . . 16
A. Exceptionalism in the Law Governing Public Contract Performance and Performance

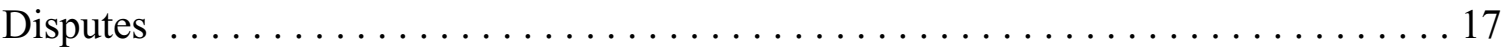
B. Exceptionalism in Other Contexts: "Reverse" or "Positive" Exceptionalism . . . . 28
C. Genuine Exceptionalism in the United States Law of Federal Public Contract
Formation and Line-Straddling Doctrines $\ldots \ldots \ldots \ldots \ldots \ldots \ldots \ldots \ldots \ldots \ldots \ldots \ldots \ldots$
D. The Incidence of Exceptionalism $\ldots \ldots \ldots \ldots \ldots \ldots \ldots \ldots \ldots \ldots \ldots \ldots \ldots \ldots \ldots \ldots$

III. Exceptionalism and the Centrality of Military Procurement $\ldots \ldots \ldots \ldots \ldots \ldots \ldots \ldots$. . . 42

A. Comparative Analysis and a Note on Causation, Coincidence

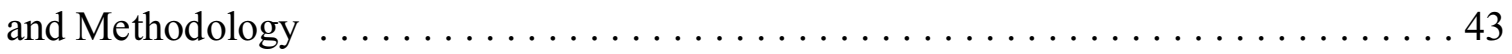

B. Centrality of Military Procurement in the United States $\ldots \ldots \ldots \ldots \ldots \ldots \ldots$

C. Military Procurement and Exceptionalism $\ldots \ldots \ldots \ldots \ldots \ldots \ldots \ldots \ldots \ldots \ldots \ldots \ldots \ldots$

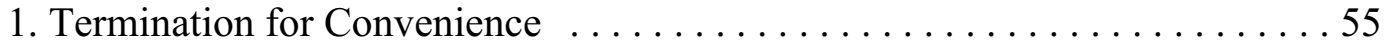

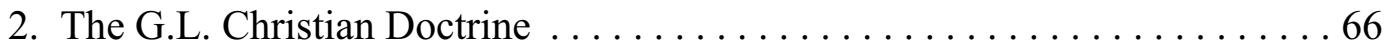

3. The Sovereign Acts and Unmistakability Doctrines . . . . . . . . . . 68

4. The deferential standard of review in judicial bid protests . . . . . . . 79

5. Other Examples of Military-Derived Exceptionalism . . . . . . . . 80

IV. Conclusions, Recommendations for Further Study and Policy Prescriptions . . . . . . 82

* Professor of Law and Co-Director of the Government Procurement Law Program, George Washington University. The author wishes to thank Dean Michael Young for grant funding that supported the writing of this article. My sincere appreciation goes, as well, to my Government Contracts Program co-director, Steve Schooner, to Government Contracts Program colleagues Fred Lees and Chris Yukins, to George Washington University Law School colleagues Jack Friedenthal, Sean Murphy and Jonathan Siegel, and to Martin Trybus of the University of Nottingham, for discussions that were of immeasurable help in the production of this article. Steve Schooner and Martin Trybus also provided invaluable comments on earlier drafts of this Article. Responsibility for any and all errors, remains, of course, my own. Please do not quote or cite this draft without the author's permission. 
Centrality of U.S. Military Procurement (Draft 10/17/04), page 2

\section{Introduction}

Over the course of the last decade the present author has consistently asserted that United States federal government procurement law may most usefully be understood by reference to a spectrum running between polar opposite approaches labeled "exceptionalism" and "congruence." "Exceptionalism," as I initially defined it, is the idea that "because of its sovereign status, unique functions, and special responsibilities, the United States Government as a contracting party is not subject to all of the legal obligations and liabilities of private contracting parties." The opposing norm of "congruence" embodies "the tendency to construe the obligations and liabilities of the United States Government under its contracts to conform to those of private parties under purely private agreements." ${ }^{22}$ In short, this spectrum gauges the degree to which aspects of federal public procurement law diverge from the rules of private contract law that govern comparable issues and does so in respects that favor the government of the United States. ${ }^{3}$

${ }^{1}$ Joshua I. Schwartz, Liability for Sovereign Acts: Congruence and Exceptionalism in Government Contracts Law, 64 Geo. WASH. L. Rev. 633, 637 (1996)(hereinafter Liability for Sovereign Acts). See also Joshua I. Schwartz, Assembling Winstar: Triumph of the Ideal of Congruence in Government Contracts Law, 26 PuB. Con. L. J. 481, 489-492 (1997) (hereinafter Assembling Winstar); Joshua I. Schwartz, The Status of the Sovereign Acts and Unmistakability Doctrines in the Wake of Winstar: An Interim Report, 51 Ala. L. Rev. 1177, 1192-1193 \& n. 61 (2000) (hereinafter Wake of Winstar); Joshua I. Schwartz, Learning from the United States' Procurement Law Experience: On "Law Transfer" and Its Limitations, 11 Pub. Proc. L. Rev. 115, 117-118 (2002) (hereinafter Learning from the United States' Procurement Experience.) .

${ }^{2}$ Schwartz, Assembling $\underline{\text { Winstar, }}$ supra note 1, at 490

${ }^{3}$ In my own work, at least, these constructs have not been deployed to gauge the degree to which the public contracts law of the States of the United States depart from the norms of their private contract law. That undertaking is certainly worthwhile, however. For readers without a background in United States law, it is important to emphasize here that the body of public procurement law described in this Article as "United States Federal Public Procurement Law" 


\section{Centrality of U.S. Military Procurement (Draft 10/17/04), page 3}

The author has argued, further, that the Supreme Court of the United States has never recognized, much less resolved, the tension between the exceptionalist and congruence approaches both found within the corpus of the United States federal government contract law. ${ }^{4}$ Nonetheless, from an analytical point of view, the contrast between these opposing tendencies provides a key organizing construct - indeed, I have suggested, perhaps, the central construct for the study and understanding of United States government contracts law. ${ }^{5}$ In addition, although the exceptionalism/congruence spectrum initially was proposed as a device for understanding United States public procurement law in a purely domestic context, the utility of

governs only the transactions entered into by the federal -that is the national-government of the United States. Moreover, the States are essentially free to frame their own procurement law systems and they need not track a single model in doing so. Thus, further research could demonstrate variation in the degree to which the States adhere to an exceptionalist or congruence-oriented approach.

It may be particularly worthwhile to undertake the extension of these concepts to representative examples of state procurement law systems, precisely because the United States Constitution does not allow the States any significant military procurement role. Accordingly, the absence of military procurement from the development of state procurement systems might have affected their approach to issues of exceptionalism and congruence in a manner that would shed further light on the thesis advanced in this Article. As noted below, this but one of the suggestions for further research that emerges from the present study. See infra TAN

${ }^{4}$ This is the essential thesis of Liability for Sovereign Acts, supra note 1. See especially, $i d$. at 637-638, 650-651, 697-702. Despite language in a plurality opinion in the Winstar case (518 U.S. 839 (1996)) that might be thought to side decisively with the norm of congruence, the author has argued in subsequent articles that neither the Supreme Court's decision in that case (in which there was no majority opinion), nor subsequent developments in this field of law, have in fact significantly alleviated this tension, nor even recognized the conflict in the existing law. Schwartz, Assembling Winstar, supra note 1, passim; Schwartz, Wake of Winstar, supra note 1, passim

${ }^{5}$ Joshua I. Schwartz, CASEs And Materials for a Survey of Government Procurement Law 43-45 (desktop published, Fall 2004 ed.) (hereinafter "Procurement Law Cases and Materials"). 
Centrality of U.S. Military Procurement (Draft 10/17/04), page 4

this construct in comparative law contexts has also been recognized. The author has invoked this construct as a tool for exploring the development of public procurement law in developing nations, and in addressing the problem of transferability of "best practices" for public procurement from developed nations to developing nations. ${ }^{6}$

It is time to take a closer look at the phenomenon of exceptionalism that characterizes so much of United States public procurement law. The examination undertaken here has several important dimensions.

The first element, is to delineate more precisely the incidence and scope of the exceptionalist tendency that I have identified in United States government contracts law. On closer examination, it is discernible that this exceptionalist tendency is primarily, though not exclusively, manifested in doctrines concerning the performance, rather than the formation of United States government contracts. ${ }^{7}$ There certainly are aspects of the law of public contract formation that might be labeled "exceptionalist" in the sense that they represent departures from the norms of private contract law in the area of contract formation. On examination, however, these, for the most part, are doctrines that impose additional obligations and duties on the

\footnotetext{
${ }^{6}$ Learning from the United States' Procurement Law Experience, supra note 1, at 117-
} 118.

${ }^{7}$ The law of government contract formation, in the United States, addresses the processes by which contracting opportunities are publicized, the criteria for contract award, processes for the selection of the appropriate contractor, and the availability of "bid protest" litigation in judicial and administrative forums to challenge a governmental agency's choice of contractor. The law of government contract performance, in the United States, governs problems that arise during the performance of the contract, including the resolution of disputes in administrative and judicial forums. The distinction between the law of government contract formation and the law of government contract performance is the central organizing dichotomy that governs the teaching of federal government contracts law in the United States. 


\section{Centrality of U.S. Military Procurement (Draft 10/17/04), page 5}

government with respect to contract formation, obligations that are not shared by private contracting parties. The paradigmatic example of such special obligations is the duty to secure full and open competition in awarding most government contracts and the procedural requirements that implement this overriding duty. ${ }^{8}$ By contrast, departures from the norms and rules of private contract law in the area of federal public contract performance law, generally entail either 1) special immunities that reduce or eliminate the liability of the United States for conduct that might be deemed a breach of contract were it committed by a party to a private sector contract, or 2) powers allowed to the United States to alter its own contracts that would render a private contract void on the ground that it is illusory or unsupported by consideration. It is this "negative" form of exceptionalism that reduces the government's obligations or expands its powers vis a vis contractors that more properly defines what the author has labeled the exceptionalist tendency in the United States public procurement law system. ${ }^{9}$ By contrast the

\footnotetext{
${ }^{8}$ See infra TAN ___ _
}

${ }^{9}$ Previously, in a somewhat different, but still relevant context, the present author has employed this nomenclature of "exceptionalism" to describe both the reasoning behind and the practical operation of the Supreme Court's administrative law cases that immunize the government from operation of the private law doctrine of equitable estoppel. See Joshua I. Schwartz, The Irresistible Force Meets the Immovable Object: Estoppel Remedies for An Agency's Violation of Its Own Regulations or Other Misconduct, 44 Admin. L. Rev. 653, 664 (1992) (hereinafter "The Irresistible Force"). That earlier work identified as a central weakness of this body of law the fact that the Court was attuned exclusively to the special obligations and responsibilities of the government, and the special requirements of relevant Constitutional texts, that tended to justify shielding it from the duties and liabilities applicable to private parties, labeling this approach "negative exceptionalism." Id. at 664-668. At the same time, The Irresistible Force argued, the Court was inappropriately oblivious to factors and doctrines -such as the Due Process Clause of the Constitution--that might suggest that the United States government enjoys special responsibilities toward those with whom it engages that are not shared by private parties. $I d$. at 726-742. The approach suggested by the latter branch of my argument in The Irresistible Force promotes "positive exceptionalism" as that term is employed here. 


\section{Centrality of U.S. Military Procurement (Draft 10/17/04), page 6}

reverse phenomenon, positive departures from the norms of private contract law that impose extra obligations on the United States in contracting, especially in the public contract formation process, the author will label "reverse exceptionalsim."

In order to substantiate the present author's first major hypothesis- that this phenomenon defined here as "exceptionalism" is primarily associated with the United States' law of government contract performance - this Article presents a survey, identifying many of the most telling examples of exceptionalism in the operation of the United States' public procurement law. These examples cluster quite strikingly in the area of government contract performance rules. By contrast, our doctrinal survey will confirm that the law of government contract formation also departs from the norms of the law of private contracts, for instance by requiring full and open competition and specifying mandatory procedures to ensure achievement of that objective. However, as suggested above, the survey also confirms that these departures are primarily such as to impose additional duties and obligations on the government, rather than to limit its liabilities or lend it atypical powers. Thus United States law of public contract formation is typified by reverse exceptionalism, not by the exceptionalist tendency defined here.

Careful study of the incidence of exceptionalism in the United States' government procurement law will assuredly sharpen our understanding of the nature and operation of the United States public procurement system viewed in a purely domestic law context. However, recognizing the performance law focus of the exceptionalist aspects of United States government contracts system becomes particularly significant when that system is viewed in comparative law perspective. In contrast to the procurement law of the United States which addresses both issues of contract formation and contract performance, the practice of European Community public 


\section{Centrality of U.S. Military Procurement (Draft 10/17/04), page 7}

procurement law as well at that of many of the major European nations is to treat rules of contract performance as lying outside the corpus of public contract law. The theory appears to be that the private contracts law of the individual Member States governs the performance and enforcement of public contracts once they are duly entered into. ${ }^{10}$ This, on its face, amounts to a commitment to an approach to government contracts performance law that we would label congruence-based.

To be sure, in some national European and other civil law procurement law systems, rules of law concerning public contract performance that plainly are recognizable as "exceptionalist" have been established with respect to an ill-defined subset of public contracts denominated as "administrative contracts." not in practical effect an important part of the law of public contracts in the countries that employ

${ }^{10}$ There is some variation on this point among the European Community Member States, with Germany and the United Kingdom adhering to this pattern and with France most inclined to create exceptionalist government procurement law extending to the field of contract performance. Wolfgang Kirchhoff, Frederick J. Lees, Daniel Mitterhoff, Joshua I. Schwartz, Nigel Shipman, Report on the Government Procurement Law of the People’s Republic OF China, (International Republican Institute, May 2001), at 20; Sue Arrowsmith, John Linarelli \& Don Wallace, Jr., Regulating Public Procurement: National and International Perspectives (Kluwer 2000), at 190, 192; Joshua Schwartz, supra note 5, at 479-480.

${ }^{11}$ Schwartz, supra note 5, at 479-480. See Laurence Folliot-Lalliot, French Public Contracts, forthcoming __ West's International Government Contractor __ (200x) Part I, Chap. 2. See also Jose Guilherme Giacomuzzi, Dissertation Proposal (Spring 2004), pp. 3-9, citing: René Chapus, Droit Administratif General vol. 1, § 724, 551 (15d ed., Montchrestien 2001) (on French law); José Cretella, Jr., Dos Contratos Administrativos 38 (Forense 2001) (on Brazilian law); Eduardo García de Enterría \& Tomás-Ramón Fernández, Curso de Derecho Administrativo vol. 1, 658-755 (9th ed., Civitas 1999) (on Spanish law); Massimo Severo Giannini, Istituzioni di Diritto Amministrativo, 498-540 (2d ed., Giuffrè 2000) (on Italian law); Harmut Maurer, Droit Administraif Allemand, 359-400 (translator Michel Fromont, L.G.D.J. 1994) (on German law). 


\section{Centrality of U.S. Military Procurement (Draft 10/17/04), page 8}

the special category of "administrative contracts." So exceptionalism regarding the rules of contract performance is not a complete stranger to public procurement law in Europe and other civil law traditions. Nonetheless, accurate and penetrating comparative law analysis in the field of public procurement law is significantly undermined by the fact that the threshold definition of the scope and coverage of public procurement law is different in the United States from that employed in much of Europe and elsewhere.

Specifically, because the exceptionalist aspects of United States public procurement law system are most strikingly evidenced in doctrines governing matters that Europeans and Civilians often portray as predominantly outside the scope of public procurement law, significant differences between European and United States public procurement law will be obscured unless the broadest view is taken of the field of public contract law. Conversely, any meaningful comparative assessment must start with, and gauge accurately, the disparities between the respective approaches to defining the field of public contracts law rules. It is suggested herebelow - that the exceptionalism/congruence spectrum has the potential to be a particularly useful device for comparative law studies of public procurement law, transcending some of the conventional difficulties associated with comparison in isolation of seemingly parallel portions of disparate legal systems. Accordingly, it will be important, for that additional reason, to be attentive to the manner in which the primary locus of United States public procurement law exceptionalism cuts across the boundaries erected by disparate definitions of the ambit of public procurement law.

A second major thread to the re-examination of exceptionalism in United States government procurement law system undertaken here seeks to identify and understand the 


\section{Centrality of U.S. Military Procurement (Draft 10/17/04), page 9}

reason(s) for the prevalence of a strong exceptionalist influence in that system. Here it is claimed that the historic centrality of military procurement in the development of the United States procurement law regime --itself a relatively unusual phenomenon when viewed in comparative perspective, is the single most important cause for the strongly exceptionalist flavor of much of the United States' public procurement law. ${ }^{12}$ Numerous examples are presented to support this conclusion. The basic modes of analysis employed to support this causal explanation are historical and doctrinal: a survey of the development of key exceptionalist features of the United States procurement law regime, identifying the role played by military procurement in the emergence of the relevant doctrines in key cases.

Although the underlying policy considerations will bear closer examination as we work through the examples that support my causal explanation, it certainly should not be surprising that engrossing military procurement within the system of public procurement law would shift the law of public procurement in an exceptionalist direction. At least in the United States' judicial tradition, but likely elsewhere as well, courts generally will be least prepared to strictly or independently scrutinize the justification for government action whenever military necessity or national security interests are invoked. In addition, the shifting fortunes of war and the accompanying "fog of war" commonly produce circumstances that were not foreseen at the time the parties entered into contracts related to military activities. Finally, contracts for military equipment commonly seek goods and services that are subject to unusually rapid technological innovation that makes frequent changes in specifications and needs especially common. For all

${ }^{12}$ In referring to military procurement here, I refer both to procurement of armaments-"hard defense procurement" and procurement of other categories of goods and services the need for and of use which may not be unique to military contexts. 
Centrality of U.S. Military Procurement (Draft 10/17/04), page 10

these reasons, departures by government from its contractual commitments will be most readily excused in such military contexts. Retention of flexibility to adjust to unforeseen circumstances will be most compellingly justified in such contexts. In short, justification for departures from the rules of private contractual obligation and excuse will be most compelling in military procurement cases. Many systems of procurement law outside the United States have exempted military procurement from the coverage of their requirements precisely to respond to these important policy considerations. However, as we see in more detail below, when the procurement law system is built around the needs and exigencies of military procurement, as was the case in the United States, the procurement law doctrine that results is far more likely to build in the substantial flexibility and significant latitude for adjustment of government obligations, powers and immunities of the kind that we have labeled exceptionalism.

The central role played by military procurement in the development of the exceptionalist tendency in United States public procurement law has evident importance for an understanding of the interplay of congruence and exceptionalism in United States public procurement law even if that body of law were still to be studied in isolation, as long was the custom of United States government contracts lawyers. However, just as the locus of exceptionalism in the United States law governing performance of government contracts had both domestic and comparative law significance, so too does role played by military procurement in providing the primacy explanation for exceptionalism in the procurement law regime of the United States. Although a full exploration of this point transcends the reach of this paper, an association will be suggested between exclusion of military procurement from the coverage of many procurement law regimes outside the United States, and the tendency toward emphasizing congruence over exceptionalism 


\section{Centrality of U.S. Military Procurement (Draft 10/17/04), page 11}

in the law governing the rights and responsibilities of government regarding performance of government contracts in such systems.

Ideally, this association should be more fully explored by examining the public procurement law of many nations to demonstrate more comprehensively the correlation between exclusion of military procurement from regulation and a adoption of a congruence-oriented approach to public contract performance law and norms. The goal of such further study would be to corroborate the present hypothesis: that a strong exceptionalist bent is more likely to blossom when military procurement is included within the rules governing public procurement generally. If this correlation is borne out, and if, as is claimed here, coverage of military procurement is a significant cause of the exceptionalist bent of the United States' procurement law system, this relationship suggests strong policy consequences that should be carefully considered by developing and transitional economies seeking to implement western style transparent and competitive public procurement regimes, as well as by experts seeking to foster the transfer of best practices from the United States to developing nations. I seek here to build the case for the suggestion that I previously have made that

the United States' experience provides evidence that suggests that . . . inclusion [of military procurement within the coverage of a nascent scheme of procurement law in a developing nation] may be very helpful to the development of key flexibility devices within the corpus of government procurement law- both to the recognition of the policy needs that such devices serve and to the legitimacy they can possess. ${ }^{13}$

It is entirely understandable that political and/or judicial decisions to exclude military procurement from the coverage of a new procurement law regime may make procurement regulation and reform more palatable politically in some quarters in developing and transitional

13، Id. at 117. 
Centrality of U.S. Military Procurement (Draft 10/17/04), page 12

regimes. Still, such decisions may have unintended consequences even for the character of the public procurement law regime governing non-military procurement. The distinctive contribution that military procurement has made to the exceptionalist character of United States public procurement law has been important, perhaps indeed essential, to the emergence of the flexibility devices that are key hallmark of that procurement regime. Moreover, it is suggested both here, and in the author's previous work, that this exceptionalist character is, generally speaking, a positive legacy of the development of procurement rules designed for a template of military procurement. In sum, exclusion of military procurement from the coverage of procurement law in emerging procurement systems may have negative spillover effects that transcend the area of military procurement itself.

Finally, the present examination of the exceptionalist tendency in the United States public procurement system is important the exceptionalism/congruence spectrum has value as a tool that can enhance comparative law analysis in the field of public procurement law. Plainly a direct comparison, in isolation, of features of disparate legal systems, even when those features appear to fill parallel functions and occupy comparable niches, is hazardous, and likely to be confusing and unreliable, if not downright misleading. ${ }^{14}$ The exceptionalism/congruence

\footnotetext{
${ }^{14}$ In the introduction to their treatise on comparative law, Zweigert and Kotz explain the inherent difficulty of the comparative law enterprise:

Comparative lawyers have long known that only rules which perform the same function and address the same real problem or conflict of interests can profitably be compared. They also know that they must cut themselves loose from their own doctrinal and juridical preconceptions and liberate themselves from their own cultural context in order to discover 'neutral' concepts with which to describe such problems or conflicts of interest .... Legal sociologists not only accept this but apply it with a rigor which the comparative lawyer finds stimulating, if a bit worrying, for legal sociologists can sometimes show that concepts and features which the comparative lawyer regards as
} 
Centrality of U.S. Military Procurement (Draft 10/17/04), page 13

spectrum, however, is a construct that can help us sidestep some of the pitfalls entailed in such direct comparisons.

For that construct is based on a comparison that operates, initially, within the confines of a given legal system. That is, this approach starts with a comparison of a particular feature of the law of government contracts in a given legal system with the analogous rules concerning private contracting, within the same legal system. Specifically, this construct poses the question of whether government contracting parties and private contracting parties have different liabilities and immunities with regard to the performance or alteration of their respective agreements. Under the approach suggested here, it is only after that initial assessment of congruence and

'neutral' and therefore suitable for the definition of the problem are in fact nationally or culturally conditioned, or that they implicitly presuppose the existence of a particular social context which in reality only exists in one of the places under comparison and not in the other.

Konrad Zweigert \& Heinrich Kotz, Introduction to Comparative Law (3d ed., Tr. Tony Weir; Oxford U. Press, 1998), p. 10-11. For further elaboration of this point, see also id. at 3640 .

John Henry Merryman has explained some of the hazards and pitfalls of attempting to do comparative law analysis:

Legal rules are what most people think of as law, and a good deal of the work of comparative lawyers is devoted to the description and evaluation of such rules. Much of the concern about the divergence of legal systems is phrased in terms of rules, and much of the effort toward unification of law is rule-oriented. But there is a very important sense in which a focus on rules is superficial and misleading: superficial because because rules literally lie on the surface of legal systems whose true dimensions are found elsewhere; misleading because we are led to assume that if rules are made to resemble each other something significant by way of rapprochement has been accomplished ....

John Henry Merryman, The Convergence (and Divergence of the Civil Law and the Common Law, in Mauro Cappelletti (ed.), New Perspectives for a Common Law of Europe (Boston, Sijthoff Pub. Co. 1978), p. 222-223, quoted in John H. Barton, James Lowell Gibbs, Jr., Victor Hao Li \& John Henry Merryman, Law in Radically Different Cultures (West Pub. Co. 1983), p. 1. 
Centrality of U.S. Military Procurement (Draft 10/17/04), page 14

exceptionalism within a particular legal system has been undertaken that comparisons are to be drawn directly between two legal systems.

Once the initial assessment of exceptionalism and congruence has been made within each of the systems to be compared, a valid meta-comparison between two systems can and should be made, analysis focusing on the degree of exceptionalism or congruence manifested within each of the systems being compared. Proceeding in this manner, it is possible to compare systems without running so seriously afoul of the problems that are conventionally understood to make more direct comparison of isolated bits of disparate legal systems inherently confusing, unreliable and misleading. While this article does not presume to implement this plan of comparative analysis, comparing the United States' procurement law system and any other public procurement law system, in any comprehensive fashion, it does offer preliminary evidence to support the conclusion that coverage of military procurement within a nation's procurement law system is correlated with an exceptionalist approach to procurement law and policy and that exclusion of military procurement is associated with a congruence approach. In addition, this Article delineates a method for undertaking such a comparative analysis and makes an argument for special utility of comparative analysis employing this approach.

The next portion of this Article, Part II, comprises a survey of significant exceptionalist doctrines in the United States' law of public procurement. There I seek to sharpen our definition of exceptionalism, to identify the primary locus of exceptionalism, and to substantiate the strong association that the author has postulated between the law of performance of government contracts and the exceptionalist tendency within the larger corpus of United States government contract law. The survey of exceptionalist doctrines demonstrates that exceptionalism in the law 
of public procurement, as I have defined it here, is primarily, though not exclusively, a creature of the law governing federal public contract performance, rather than contract formation.

Part III of this Article makes the case for a strong causal link between the consistent centrality of military procurement in the development of the procurement legal regime in the United States and the striking exceptionalist strain in United States' public procurement law. Initially, in Part III(A), we confront a methodological difficulty inherent in making this kind of claim about the "causes" of an important feature of United States law, or any analogous claim about the antecedents of any legal doctrine. This difficulty is in part a product of the inherent difficulty of establishing historic causation in any setting, and a fortiori in attempting to account for the origins of any legal doctrine. But the difficulty is also inherent in the nature of the comparative law enterprise to which this Article seeks to make a contribution. While these difficulties of causal explanation and comparative analysis are real, and must be acknowledged forthrightly, this Article identifies a methodology that enables us to move the argument forward, without pretending to complete the comparative analysis. Like much scholarship that proposes an analytical framework for a distinctive body of law, this Article invites extension of the work presented in the form of contributions from other scholars examining the same problems in different legal settings, including those of radically different legal cultures.

Part III(B) of this Article attempts, in relatively brief compass, to establish a basic claim that is predominantly descriptive, about the United States' procurement law system. This is a claim the truth of which probably is taken for granted by those who are familiar with that system. It is simply that military procurement and its regulation have served as the template for the development of the entire United States public procurement law regime, both historically, and on 
Centrality of U.S. Military Procurement (Draft 10/17/04), page 16

into the current era. At least until the post-World War II era, civilian agency procurement and its regulation were been relatively minor parts of this regulatory system. Civilian procurement was not the main driving force behind the development of the innovative legal regime that supports the United States' federal public procurement system. Although this point is taken for granted by many who are knowledgeable about the operation of the United States' system, the centrality of military procurement to the regulated procurement system of the United States in fact distinguishes it from the transparent and competitive procurement regimes of most other developed nations.

Finally, in Part III C, I present the causal argument about the role of military procurement in establishing an exceptionalist procurement regime. Using selected, but representative, examples of significant exceptionalist doctrines, I endeavor to demonstrate the unusually important role that the military procurement context has played in leading judicial decisions and legislative and administrative developments that have established the exceptionalist flavor of United States federal public procurement law. Based on a review of these examples, one could hardly fail to recognize the impact of military procurement in establishing the character of this body of law. Although further comparative law analysis is required to provide another kind of evidence that could corroborate my claim here, review of the internal development of the United States federal public procurement law regime strongly supports the theory that military procurement has caused the strikingly exceptional character of that system of law.

\section{What is Exceptionalism? Where and When Does it Occur?}

To define exceptionalism in the United States law of public procurement with greater 
Centrality of U.S. Military Procurement (Draft 10/17/04), page 17

precision, it is critical, initially, to identify doctrines and practices that should be identified as leading examples of the phenomenon of exceptionalism. As indicated in the Introduction, our survey will reveal that the bulk, though surely not all, of these are to be found in the law governing federal government contract performance and disputes associated with contract performance, rather than that addressed to public contract formation. The survey that follows is necessarily selective, and the explanation of salient doctrines limited; otherwise it would inexorably develop into a treatise on the law of United States government contracts law. The watchword for what follows is to provide the reader with enough documentation to support the analysis undertaken and the conclusions drawn therefrom.

\section{A. Exceptionalism in the Law Governing Public Contract Performance and Performance}

\section{Disputes}

Among the salient examples of exceptionalism that arise in the area of the law relating to public contract performance are the following:

- the far-reaching power of federal government contracting officers to terminate a contract "for the convenience of the government" in a very wide range of circumstances, even in the absence of any contractor's breach, without incurring full liability for expectancy damages $^{15}$

${ }^{15}$ See, e.g. 48 C.F.R. $§ 52.249-2$ (FAR prescribed standardized Termination for Convenience Clause for fixed-price contracts for goods and services). See John Cibinic \& Ralph Nash, Administration of Government Contracts(3d ed. 1995) (hereinafter "ADMINISTRATION"), at 1073-1134. Fact patterns in which termination for convenience may successfully be invoked plainly include many in which the government's action, would if the clause is inapplicable or unenforceable, be a breach of contract, giving rise to full loss-of-profits expectancy damages, just as these facts would in a dispute between parties to a private contract. 
Centrality of U.S. Military Procurement (Draft 10/17/04), page 18

- the broad power of federal government contracting officers unilaterally to institute substantial changes in the scope and nature of the work to be performed under the contract, in return for which the contractor is assured of an "equitable adjustment" -without the government either incurring full liability for breach (at the time of the unilateral change order) or voiding the contract $a b$ initio $;^{16}$

- the broad power of federal government contracting officers unilaterally to suspend or defer the performance of a government contract, again without either incurring full liability for breach or voiding the contract, in return for which the contractor is again assured an "equitable adjustment;","17

In addition, the broad power conferred by the termination for convenience clause risks depriving the government contract of consideration sufficient to render it enforceable, at least under the standards of private contracts. See Torncello v. United States, 681 F.2d 756, 768-772 (Ct. Cl. 1982) (opinion of Bennett, J.); see also G.L. Christian \& Assoc. v. United States, 312 F.2d 418, 423-424 (Ct. Cl. 1965), cert. denied, 382 U.S. 821 (1965) (portraying breach as "normal" contract law classification for conduct treated as subject to termination for convenience clause, where it is applicable).

${ }^{16}$ See, e.g 48 C.F.R. $§ ~ 52.243-1$ (Federal Acquisition Regulation (hereinafter "FAR") provision prescribing a standardized changes clause for inclusion in fixed price contracts). See, Cibinic \& Nash, Administration, supra note 15, at 381-485 (summarizing the law of public contract "changes"). Such changes would, which may radically alter the performance that the contract is called upon to deliver or the profit that it may ultimately receive, would in the context of an ordinary private contract, likely be considered breaches of the contract. This appears particularly to be true in cases where the constructive change label was applied after the fact by a court to requirements imposed by the the contracting officer that he or she did not contemporaneously recognize as enlarging the contractor's obligations beyond those prescribed in contract itself. See, e.g. W. H. Edwards Enginr'g Co. v. United States, 161 Ct. Cl. 322 (1963). Alternatively, in an ordinary private contract the retention of the power unilaterally to make such changes might well be considered to make the government's contractual undertaking "illusory" and the contract, accordingly, unenforceable.

${ }^{17}$ See, e.g. 48 C.F.R. $\$ 52.212-12$ (FAR-prescribed standardized Suspension of Work clause for fixed price construction contract); 48 C.F.R. $\S 52.212-13$ (FAR-prescribed standardized Stop-Work Order Clause for contracts for supply of goods or services); 48 C.F.R. $\S$ 
Centrality of U.S. Military Procurement (Draft 10/17/04), page 19

- the "strict compliance rule": that is, the absence of any materiality threshold when the government wishes to terminate a government contract for default because of defects in the contractor's performance $;^{18}$

52.212-15 (FAR-prescribed standardized constructive suspension clause for use in contracts for the supply of goods or services). See Cibinic \& Nash, Administration, supra note 15, at 586618. Like the institution of a change order, a suspension order or constructive suspension arising from delay covered by the foregoing provisions, might well, in their absence, be regarded as a fully compensable breach of contract. This is particularly true of the constructive suspension authority, which takes effect with regard to delays that were not contemporaneously characterized by a contracting officer as an exercise of suspension authority. See, e.g. Hoel-Steffen Construc. Co., 456 F.2d 460 (Ct. of Cl. 1972)(illustrating that fact pattern). Alternatively, the government's retention in the contract of this broad authority unilaterally to adjust the timing required for the contractor's performance and the timing of its own contractually obligated payments, might well, in an ordinary private contract, render the agreement illusory and unenforceable.

${ }^{18}$ See, e.g. Arrow Lacquer Corp., ASBCA No. 4667, Navy Appeals Panel, Contract \# N383-32050A (Oct. 31, 1958)(slight color deviation from standard in color of primer coat of paint is ground for termination for default even though the primer coast is covered by a top coat and no suggestion was made as to how or why the trivial color discrepancy might affect performance); De Vito v. United States, 413 F.2d 1147, 1154-1155 (Ct. Cl. 1969) (time is "of the essence" in any government contract containing a fixed date for performance-unless the time for performance is waived by the words or deeds of authorized government agents); but see Franklin E. Penny Co. v. United States, 524 F.2d 668 (Ct. Cl. 1975) (suggesting that time was not necessarily always of the essence in a government contract). See Cibinic \& Nash, ADMINISTRATION, supra note 15, at 908-918.

Note that the FAR provisions governing default termination generally provide three categories of grounds for such termination: 1) violation of a qualitative performance specification, 2) actually missing an interim or final contractual performance deadline, and 3) conduct that seriously endangers the ultimate timely performance of the contract,. See, e.g. 48 C.F.R. $\S 52.249-8$ (prescribing a standardized termination for default clause for fixed price supply and service contracts). The very existence of the third category reveals that, both as to timeliness and as to measures of qualitative performance, the government contractor has less latitude than its counterpart on a purely private contract to avoid liability by asserting that any shortcoming of its own performance was non-material. 
Centrality of U.S. Military Procurement (Draft 10/17/04), page 20

- the government's right to terminate a contractor for default because of the contractor's slow progress that endangers ultimate timely performance even where the contractor has not missed any ultimate or interim contractual deadline or benchmark for performance ${ }^{19}$ - the principles of Clearfield Trust ${ }^{20}$ and its sequelae, ${ }^{21}$ which establish that interpretation of federal government contracts is, inherently, a question of federal law, even though state law would generally govern disputes arising under private contracts that are adjudicated in federal court. ${ }^{22}$ These principles dictate, moreover, that federal judge-made law

\footnotetext{
${ }^{19}$ This noteworthy exceptionalist feature of the law about default termination of federal public contracts is expressly reflected in the termination for default clause. See, e.g. 48 C.F.R. $\S$ 52.249-8 (default termination clause for fixed price supply and service contracts.) The second of the three generic grounds for default termination of a federal public contract that is noted above-endangering the ultimate timely performance of a government contract-does not appear to have any full counterpart in the law of private contracts. This provision allows the government to terminate when the contractor has not actually missed any fixed contractual requirement of timely performance. Cibinic \& Nash, Administration, supra note 15, at 929-935. Such a failure to progress without actually missing a deadline for performance under the contract would not, absent the exceptional provisions of the standard clauses governing termination for default of government contracts, constitute a breach by the contractor were the standards that apply to private agreements to be applied. United States v. O'Brien, 220 U.S. 321, 327 (1911) (Holmes, J.) (contrasting federal procurement doctrine with state contract law on this point).

${ }^{20}$ Clearfield Trust Co. v. United States, 318 U.S. 363 (1943).

${ }^{21}$ See United States v. Kimbell Foods, Inc. 440 U.S. 715 (1979) (refining, applying and distinguishing Clearfield Trust as described further infra note 23).

${ }^{22}$ Clearfield was noteworthy, and perhaps a surprise because it was decided shortly after Erie R. Co. v. Tompkins, 304 U.S. 64 (1938), had strongly underscored the importance, for federalism reasons, of using state law rules as the rules of decision for cases decided in federal courts, absent a rule of decision provided by the federal positive law. It is familiar ground that Erie rested in part on the Rules of Decision Act, 28 U.S.C. $§ 1652$, and in part on principles of constitutional federalism. The well-known holding of Erie is the categorical declaration that "[t]here is no federal general common law." 304 U.S. at 78.

In Clearfield the issue was whether the rights of the United States with respect to commercial paper that it issues-a government check- are governed by state or federal law.
} 
should ordinarily be fashioned to fill any gaps in the relevant positive law, leaving little occasion for the borrowing of the state law rules that normally govern private contracts to fill these gaps. ${ }^{23}$

There was no federal statute addressing the specific issue presented and the relevant federal regulations did not address the specific question presented either. 318 U.S. at 366-367 \& n.2. Moreover the Court did not identify any constitutional provision that dictated the rule of decision or dictated that it be a federal rule of decision. Although the Rules of Decision Act itself specifies that state law should govern disputes in federal court "except where the Constitution or treaties of the United States otherwise require or provide," 28 U.S.C. $\$ 1652$ (emphasis added), the Court nonetheless concluded that federal law- if necessary, judge-made- should control the case. The Court explained:

When the United States disburses its funds or pays its debts, it is exercising a constitutional function or power. This check was issued for services performed under the Federal Emergency Relief Act of 1935, 49 Stat. 115. The authority to issue the check had its origin in the Constitution and the statutes of the United States and was in no way dependent on the laws of Pennsylvania or any other state .... The duties imposed on the United States and the rights acquired by it as a result of that issuance find their roots in the same federal sources. In the absence of an applicable Act of Congress it is for the federal courts to fashion the governing rule according to their own standards ....

318 U.S. at 366-367 (emphasis added; footnote omitted.) What is significant here is just how weak the argument for application of federal law should have appeared in light of the then-recent Erie decision. There was no applicable Constitutional provision cited, and no constitutional "require[ment] or provi[sion]" dictating a federal rule of decision can be identified. Similarly, no statutory basis for the application of federal law can be identified that appears to rise to the level of a "require[ment] or provi[sion]" dictating creation of a federal rule of decision. The fact that federal government contracts arise out of the functioning of the federal government seems to be enough to dictate a federal rule of decision, even though the threshold for escaping the operation of the Rules of Decision Act had not been met in literal terms. And the court ignores entirely any obstacle to this result posed by the extra-statutory dimension given to the Rules of Decision Act in Erie itself.

${ }^{23}$ It is important to recognize that Clearfield has this second layer of exceptionalism, in addition to the first. Even after the Court determined that the rule of decision should be federal, and judge-made, if there is a gap in relevant positive federal law, the Court goes on to consider the subsidiary question whether, in fashioning federal common law to meet the needs of the case for a rule of decision, a federal court should borrow-that is, voluntarily adopt as its own- the relevant state law decisional law. Id. at 367. But the Court rejected that alternative for most 
Centrality of U.S. Military Procurement (Draft 10/17/04), page 22

federal contract disputes, noting that federal government's powerful interest in having a uniform set of rules to govern its vast array of contracts-in this case checks- of a particular character required that there be a uniform federal rule of decision, rather than a borrowing of any state law. Id.

The exceptionalist character of the rule of Clearfield is underscored in deliciously ironic fashion when the Supreme Court then proceeded, entirely unselfconsciously it appears, to justify the creation of a federal body of commercial common law to govern cases like this, by pointing to the availability of the body of "federal law merchant, developed for about a century under the regime of Swift v. Tyson, 16 Pet. 1," which "stands as a convenient source of reference for fashioning federal rules applicable to these federal questions." 318 U.S. at 367. Of course, Swift v. Tyson is the decision that was overruled by Erie, which effectively decreed that this body of "federal law merchant" should be no more!

Despite the doubly exceptionalist approach taken in Clearfield, the subsequent decision in Kimbell Foods (see supra note 20) has qualified this second layer of exceptionalism, but only to a modest degree and in respects unrelated to typical federal procurement contracts. In Kimbell Foods, the Court listed 3 factors that should enter into the choice whether to borrow state law rules to supply the federal rule of decision or to "fashion a nationwide [judge-made] federal rule." 440 U.S. at 727-728. These are :

- whether the particular federal program inherently requires uniform of nationwide operation that would "necessitate formulation of controlling federal rules" (id. at728);

- whether even "[a]part from considerations of uniformity . . . [borrowing] of state law[derived rules] would frustrate specific objectives of the federal programs" (id..); and

- whether the "application of a [judge-made uniform federal common law] rule would disrupt commercial relationships predicated on state law" (id. at 729). In other words, is there a strong interest in borrowing state law to decide the rights of federal parties so as to harmonize and integrate the law governing their rights with the web of law applicable to the non-federal interests.

The Clearfield rule, even as amplified by Kimbell, affords striking latitude for fashioning federal rules of decision to govern federal questions arising in disputes involving federal contracts. Moreover, the Clearfield/Kimbell analysis leaves almost no room for the borrowing of state law to govern questions arising in federal public procurement. Because of the voluminous provisions and extensive reach of the Federal Acquisition Regulation and its supplements, together with that of the federal statutes applicable to government contracts, there is relatively rarely a gap in federal positive law that even invites the possibility of borrowing state law. Moreover, even when there is such a gap, application of the Kimbell 3 factor analysis will virtually never lead to borrowing of state law. In federal procurement cases, there is invariably a compelling need for a nationally uniform rule to govern the nationally uniform activity of procurement. Morover, there are invariably strong federal interests in the operation of the federal program that would be undercut by application of state law that would preclude borrowing of 
Still other key exceptionalist rules that are applied in the law governing contract performance in the federal public procurement system include:

- the G.L. Christian ${ }^{24}$ doctrine, which holds that standardized clauses that ought to have been included in a federal government contract, but which were omitted due to an error of federal agents, should nonetheless be read into the contracts from which they were mistakenly omitted ${ }^{25}$ and

state law. See, e.g. Paul v. United States, 371 U.S. 245 (1963)(state may not constitutionally enforce its milk sale minimum price regulation with respect to contracts for sale of milk to federal instrumentalities). And finally, it would be unusual for there to be any compelling interest -arising from the need for integration of federal and private transactions- to make operation of the rules governing federal procurement track the rules governing private transactions. Most federal procurement is simply too discrete an activity to warrant any such conclusion. Schwartz, Procurement Law CASes And Materials, supra note 5, at 775-776. Taken one at a time these arguments generally are quite strong; collectively their impact will almost never permit borrowing of state law. In sum, the contrast between the unique federal law regime that governs federal procurement under federal positive law, including the FAR, together with Clearfield/Kimbell and, on the other hand, the regime of state law that governs analogous private contract disputes -even when they arise in federal court- under the Erie doctrine, reflects a profoundly exceptionalist approach.

${ }^{24}$ See G.L. Christian \& Assoc. v. United States, 312F.2d 418 (Ct. Cl. 1963), cert. denied, 382 U.S. 821 (1965).

${ }^{25}$ In G.L. Christian, the seminal case, in 1958 the United States Army had terminated, for the convenience of the government, a contract for the construction of a large complex of military personnel housing at Fort Polk, Louisiana. See infra TANs ___ for discussion of the termination for convenience clause and the associated doctrines. The termination for convenience was triggered by a decision to deactivate Fort Polk itself in 1958. The responsible contracting officer, however, evidently mistakenly omitted the standard termination for convenience clause from this construction contract. Accordingly, the contractor asserted that the government had not reserved the power to terminate for convenience and was accordingly liable for breach of contract. In practical effect, the difference was this: under a termination for convenience clause the contractor would be entitled to be made whole by allowing it recovery of all expenses reasonably incurred prior to the contract termination and unavoidable ongoing 
- the immunity of the federal government from liability under any contract "implied in law."26

expenses. By contrast, the contractor asserted the right to full expectancy damages, including recovery of the anticipated profits that it would have earned had the contract performance gone forward. 312 F.2d at 419, 423-424.

The court of appeals held that because the government's statutorily-authorized procurement regulations directed that a standardized termination for convenience clause should have been included in this construction contract, "the contract must be read as if it did," even though it actually omitted the required language. $I d$. at 424 . Some language in the court's opinion might suggest that the result was limited to cases where an experienced defense contractor specifically should have known that the omitted clause was required to be, and was intended to be, included. Id. at 426-427. However, subsequent decisions have treated this as a bright line rule and have obviated any inquiry into whether the particular contractor knew or should have known of the particular required clause that was omitted. Schwartz, Procurement LAW CASES AND Materials, supra note 5, at $\{123\}$.

${ }^{26}$ In the Tucker Act, 28 U.S.C. § 1491(a)(1), the United States waived sovereign immunity, consenting to be sued on a variety of classes of claims, including "any claim against the United States founded ... upon any express or implied contract with the United States." The Supreme Court of the United States has consistently "held that this jurisdiction extends only to contracts either express or implied in fact, and not to claims on contracts implied in law." Hercules, Inc. v. United States, 516 U.S. 417, 423 (1996). Thus the United States retains its sovereign immunity from claims under any implied in law contract. Hercules sets forth the traditional delineation between contracts implied-in-fact (on which the United States can be sued) and contracts implied in law:

The distinction between "implied in fact" and "implied in law," and the consequent limitation, is well established in our cases. An agreement implied in fact is "founded upon a meeting of minds, which, although not embodied in an express contract, is inferred, as a fact, from conduct of the parties showing, in the light of the surrounding circumstances, their tacit understanding." . . . By contrast, an agreement implied in law is a "fiction of law" where "a promise is imputed to perform a legal duty, as to repay money obtained by fraud or duress."

417 U.S. at 423-424 (citations omitted). The exceptionalist character of this particular doctrinal limitation on the liability of the United States emerges, of course, from the fact that liability for private parties operating under private agreements can arise both for breach of breach of impliedin-fact contracts and for breach of implied-in-law contracts. 
Many of the foregoing exceptionalist doctrines will be striking, indeed, to those accustomed to the norms of private contract law. Perhaps the single most striking example of the exceptionalist phenomenon, however, is the government's broad power to terminate a federal procurement contract "for the convenience of the government," noted above. ${ }^{27}$ Nonetheless, as striking as the government's special power to terminate its contracts for its own "convenience" may be, the true apotheosis of exceptionalism is found elsewhere--in the sovereign acts doctrine, and the related unmistakability doctrine, described here in the ensuing text.

These two interrelated and overlapping doctrines together require that government contracts be read to reserve to the government an extraordinary generic power. They accord the government the power to take, without incurring liability, a broad range of acts in the course of exercising of its sovereign authority to regulate and other sovereign powers. Although these acts may have the practical effect of interfering substantially with the government's own obligations under a government contract, or burdening the contractor's prescribed performance, and might appear to constitute a breach of contract were it carried out by a private party in parallel circumstances, these doctrines, where applicable, excuse the government from liability. ${ }^{28}$

${ }^{27}$ See supra TAN

${ }^{28}$ The exact contours and the history and policy foundations of the Sovereign Acts and Unmistakability Doctrines are complex, controversial and difficult subjects. There is no need for present purposes to immerse the reader in the details of these sometimes arcane doctrines. The present author has written extensively to address these matters elsewhere, and refers the interested reader to that body of earlier work for a more detailed account. See Schwartz, Liability for Sovereign Acts, supra note 1; Schwartz, Assembling Winstar, supra note 1; Schwartz, Wake of Winstar, supra note 1; Schwartz, Procurement Law Cases and Materials, supra note 5, at $\{175-178,191-196,208-209\}$.

In addition, in Part IIIC of this Article, a brief account is offered of the historical genesis of the Sovereign Acts Doctrine, which will afford the reader some concrete examples of its 
Centrality of U.S. Military Procurement (Draft 10/17/04), page 26

These last examples of exceptionalism in the law of federal public contract performance, the Sovereign Acts and Unmistakability doctrines, makes clear why these doctrines are classified as exceptionalist. Applying the norms of private contracts the kind of governments actions that are excused by these doctrines generally would be regarded as a breach of contract. ${ }^{29}$ Alternatively the very reservation of the wide-ranging immunity reserved by the government would likely void the contract, were it a private engagement, because it would render the undertaking optional or too uncertain, resulting in a failure of consideration or an illusory contract. The Sovereign Acts Doctrine and Unmistakability Doctrine also offer particularly potent evidence of the exceptionalist character of the norms of public contract performance in the United States because these particular doctrines provide allow the government a universally applicable set of rules of construction, powers and immunities, potentially overriding and supplementing a broad array of more specific doctrines of contract interpretation and performance. The government's broad termination for convenience authority shares this general characteristic of acting as a sort of "universal solvent" for normal contract obligations.

Other examples of exceptionalist contract performance-related rules with the particularly

application and typical effect. See infra TAN

${ }^{29}$ Central difficulties in mapping the contours of the Sovereign Acts and Unmistakability Doctrines arise both 1) from the fact that the government frequently enters into agreements for which there is no plausible private analogue, and 2) frequently acts in a manner that has the practical effecting of undermining the performance of its own contracts by exercising governmental powers that no private party could exercise. These twin facts underlie the policy justification for creating the sovereign acts and unmistakability doctrines. But they also render in coherent many of the courts efforts to prescribe the proper scope and effect of the operation of this doctrine. See Schwartz, Liability for Sovereign Acts, supra note 1, at 653-658; 689-691, 697-702; Schwartz, Assembling Winstar, supra note 1, at 520-523, 552-565; Schwartz, Wake of Winstar, supra note 1, at 1193-1197. 
broad reach and sweeping effect that distinguish the termination for convenience doctrine, and the Sovereign Acts and Unmistakability Doctrines that are worthy of being singled out here are the choice of law doctrine of Clearfield Trust and the omission-filling rule of G.L. Christian ${ }^{30}$ that are described above. By governing and supplementing the applicable body of law, these doctrines directly and indirectly assure that federal government contracts are interpreted and enforced under a uniform regime that is constructed to take into account the to the special needs, and policy priorities of the government, as well as the exigencies it may face. G.L. Christian effectively blends a breach-excusing rule with this kind of government-friendly specialized choice of law rule. ${ }^{31}$

Plainly a full description of the operation of each of these doctrines is beyond the reach and scope of this article. Indeed, one way of stating my basic point in this Part of this Article is to reflect that, because of their number, their far-reaching impact, and their pervasiveness in the United States' law of performance of public contracts, such a full description of these exceptionalist doctrines would convert this Article, willy-nilly, into a replication of Nash and Cibinic's leading treatise on Administration of Government Contracts. ${ }^{32}$ In the foregoing discussion, I accordingly have settled for brief explanations, with citations in the margins to sample provisions of the FAR, a few illustrative cases, and cross references to an authoritative treatise. The discussion that has been provided nonetheless should suffice to establish a key

\footnotetext{
${ }^{30}$ See supra TANs ______ (regarding Clearfield) \& note ___ (regarding G.L. Christian)

${ }^{31}$ See infra TAN ______ (regarding G.L. Christian).

${ }^{32}$ Cibinic \& Nash, Administration, supra note 15.
} 
Centrality of U.S. Military Procurement (Draft 10/17/04), page 28

aspect of my thesis in this Part of this Article: that there is a strikingly exceptionalist cast to much of the law of federal public contracts and that that tendency is prominently on display in the law that governs disputes arising out of the performance of federal public contracts. Part IIB now moves on to survey the incidence of exceptionalism elsewhere in the United States' law of federal public contracts. ${ }^{33}$

\section{B. Exceptionalism in Other Contexts: "Reverse" or "Positive" Exceptionalism}

As mentioned at the outset, government procurement law rules that have an exceptionalist cast are not entirely limited to the body of law that governs disputes about the performance of such contracts. As we shall see, this conclusion will stand even after a significant clarification as to the proper understanding of government contracts "exceptionalism" is established here. Specifically, government contracts rules are properly considered to be exceptionalist only when they excuse the government from duties or obligations that it might otherwise bear, or lend it powers or immunities that it otherwise would lack, were its rights judged under the norms applicable to private parties that have entered into private contracts. ${ }^{34}$ Exceptionalism in the law of public procurement, then, should be understood to denote only these kinds of rules, which

${ }^{33}$ For the benefit of any reader less familiar with basic public contract law doctrines, it is noted here that Part IIIC of this paper will describe in more detail the emergence of selected exceptionalist doctrines. In particular, there the reader will find a fuller account of two of the most dramatically exceptionalist doctrines that operate in the United States' law of performance of government contracts: the broad power of the United States to terminate its contracts "for the convenience of the government," and Sovereign Acts Doctrine, which saves the government from liability for breach in a wide range of circumstances.

${ }^{34}$ See supra TAN 5-7. 
reflect what the author has sometimes labeled negative exceptionalism, because they reduce the government's duties and obligations, and subject contractors to enhanced government powers and immunities. ${ }^{35}$

By contrast, there is, of course, a broad array of doctrines, primarily applicable to the formation of federal public procurement contracts, that impose procedural duties and substantive standards on the United States that a private contracting party would not bear. These requirements, might better be labeled "reverse" exceptionalism" because they increase rather than reduce the duties and obligations of the government, and are quite distinct from the phenomenon of exceptionalism that is under study here. ${ }^{36}$ Of course, one may quite plausibly view these two phenomena as inextricably intertwined facets of a single phenomenon that sets the rules of engagement for those who would enter into the government contracting market. Under these rules of engagement, the government contractor or would-be contractor is effectively told that the extra obligations the government will bear, especially in contract formation ("reverse exceptionalism"), come with a price tag in the form of the exceptionalist powers and immunities that the government will enjoy once the contract has been awarded. ${ }^{37}$

${ }^{35}$ See supra TAN notes $7-8$ \& note 8.

${ }^{36}$ See supra note 8 and accompanying text.

${ }^{37}$ This perspective would appear germane in assessing the argument that some of the features of the government contracts law regime effectively operate as barriers to entry into the market to provide goods and services to the government, and thereby undesirably contract that marketplace by discouraging and deterring entry by those not established as government contractors. See William Kovacic, Regulatory Controls as Barriers to Entry in Government Procurement, 25 Policy Sciences 29 (1991). At the same time, this perspective is not offered as a refutation to the concerns identified by Kovacic's analysis. This is in part because the cost of exceptionalism to putative contractors may outweigh the value to them of the government's 
If only to demonstrate their distinctly different cast, the most salient illustrations of this reverse exceptionalism should be mentioned very briefly here. Most importantly, these include the duties imposed on military and civilian agencies to award contracts after a process that constitutes "full and open competition," 38 unless there is both a substantive exception that is properly applicable and, moreover, the required transparent procedures necessary properly to invoke such an exception have been fulfilled. ${ }^{39}$ These also include the requirement to use an approved transparent process of securing full and open competition, usually either sealed bidding or competitive negotiation/competitive proposals, and adherence to a structured set of criteria governing the choice of competitive procedure. ${ }^{40}$ There are detailed prescriptions as to the unique affirmative obligations in some or even many settings. Moreover, it is important to emphasize that not all reverse exceptionalist burdens borne by the procuring agency under the federal procurement law regime actually translate into benefits for the contractor or would be contractor. It is more likely, however, that most, if not all, of the benefits to the government of true exceptionalism are experienced by contractors as additional costs and risks of doing business with the government. Accordingly, even though the benefits and costs to contractors of exceptionalism and reverse exceptionalism should be assessed as a package, in appraising the barriers to entry issue raised by Kovacic, that accounting must be done in particularized fashion, focusing on the distinctive impact on contractors of particular rules under scrutiny, if it is to be meaningful as a tool for policy analysis. It also remains true that there may be important public monetary and non-monetary values served by exceptionalist government contracts rules that may justify their net social cost, even if a particularized assessment were to reveal that the net effect of the government contract law regime taken as a whole is to serve as a significant barrier to entry to this marketplace.

${ }^{38} 10$ U.S.C. $\S 2304(a)(1)(A)$ (regarding military and NASA contracting); 41 U.S.C. § 253(a) (regarding contracting by most civilian agencies). For subsequent examples of such positive exceptionalist requirements, citations are given only for the statutory provisions applicable to military contracting, although there are invariably parallel provisions in the statute regulating civilian agency procurement with respect to the examples given.

$$
\begin{aligned}
& { }^{39} 10 \text { U.S.C. } \S 2304(\mathrm{c}) . \\
& { }^{40} 10 \text { U.S.C. } \S 2304(\mathrm{a})(2)
\end{aligned}
$$


criteria and procedures to be used by agencies in selecting a winning bidder or proposal from among the competing offers or proposals, ${ }^{41}$ "debriefing"-that is, advising, losing offerors as to the agency's reasons for favoring a competing proposal, ${ }^{42}$ and equally detailed rules and procedures governing the determination of whether a contractor is qualified to receive a contract award. ${ }^{43}$ In some cases the operation of the Fifth Amendment's Due Process Clause also contributes to the procedures that the government must observe in debarring a contractor, or making a recurring or stigmatizing non-responsibility determination. ${ }^{44}$ In each of these instances private parties engaging in contractual procurement do not bear these same judicially enforceable obligations or any nearly analogous set of duties. Although these are representative of some of the most salient government-unique duties that the government bears under the law of government contract formation, this scarcely exhausts the relevant category. This listing should suffice, however, to establish that although the law of government contract formation departs dramatically from the norms of private contracting, the overwhelming thrust of the departure is in the direction of imposing extra duties on the government. These tend to be duties that afford would-be government contractors the benefit of a transparent and competitive procurement regime, and thus do not resemble the kind of exceptionalism that the author has defined as a

${ }^{41} 10$ U.S.C. $\S 2305$.

${ }^{42} 10$ U.S.C. $\S 2305(b)(5)$

${ }^{43}$ See 48 C.F.R. $\S 9.103-9.104$ (FAR's basic provisions regarding responsibility determination); 48 C.F.R. $§ 9.406-2$ (FAR provisions on causes for debarment) 1980)

${ }^{44}$ Old Dominion Dairy Products, Inc. V. Secretary of Defense, 631 F.2d 953 (D.C. Cir. 
particular hallmark of the law of federal public procurement contract performance and disputes pertaining thereto. ${ }^{45}$

Of course, as important, or even more important, in practical terms, than all of the foregoing requirements, in fastening special duties on procuring government agencies that have no private sector counterparts, is the routine availability of judicial and non-judicial bid protest mechanisms that make the reverse exceptionalist doctrines enforceable. ${ }^{46}$ In realistic terms it is the assurance of the enforceability of these requirements offered by the bid protest forums that makes these substantive and procedural reverse exceptionalist requirements of value to contractors and a source of real obligation for government agencies engaged in procurement. In sum, although government contract formation is marked by substantial departures from the

45 There are, of course, also doctrines of government contract formation that tend to follow the requirements of the law of private contract formation, reflecting congruence rather than exceptionalism, except insofar as particular requirements may be specifically modified by specific exceptionalist requirements. Significant examples of such doctrines include:

- $\quad$ the rule that a binding offer followed by a binding acceptance yields a binding contract obligation (United States v. Purcell Envelope Co., 249 U.S. 313 (1919) (see infra TAN (Willard, Sutherland \& Co. v. United States, 262 U.S. 489 (1923); Torncello v. United States, 681 F.2d 756, 768-772 (Ct. Cl. 1982));

- the recognition of a "statute of frauds" requirement that most contracts be entered in writing in order to be enforceable (United States v. American Renaissance Lines, 494 F.2d 1059 (D.C. Cir. 1974); and

- the rule that implied-in-fact contracts may be recognized as obligations of the United States (Hercules, Inc. v. United States, 516 U.S. 417, $423-424$ (1996); Algonac v. Mfg. Co. v. United States, 428 F.2d 1241 (Ct. Cl. 1970)).

${ }^{46} 31$ U.S.C. $\S \S 3551-3556$ (bid protest authority of the General Accounting Office); 28 U.S.C. § 1491(b) (bid protest jurisdiction of the Court of Federal Claims; former bid protest jurisdiction of the United States District Courts, in conjunction with the federal Administrative Procedure Act, 5 U.S.C. $\S \S 701-706)$. 
Centrality of U.S. Military Procurement (Draft 10/17/04), page 33

norms of private contracting, most of those departures do not represent the exceptionalism defined previously by the author or which is the focus of this Article, which indeed characteristically is found primarily in the law of public contract performance. Some counterexamples, genuinely exceptionalist elements of the law of public contract formation and related doctrines, are considered in Part IIIC of this Article, which follows shortly.

It is also noteworthy that the reverse exceptionalist requirements found in United States public procurement law, such as the basic requirements for full and open competition and the rules governing the procedures for competitive procurement, and the availability of bid protest procedures, which were briefly listed in the Part IIB of this Article, form the heart of the common ground that exists between the norms of United States and the European Community regarding procurement. From the European Community point of view, in effect, the bulk of public procurement law lies in this category. However, as we have emphasized here, the scope of public procurement law in the United States, substantially transcends this category, encompassing the genuinely exceptionalist regime of public contract performance law that is so significant a part of the United States procurement system.

C. Genuine Exceptionalism in the United States Law of Federal Public Contract Formation and Line-Straddling Doctrines

Despite the clear predominance of doctrines governing contract performance among the exceptionalist aspects of United States public procurement law, there are certainly significant departures from the norms of private contract law that pertain to the substantive norms for 
contract formation and, most importantly, the process for selecting the government's contracting partner. As noted in the previous section of this Article, these should be subdivided further into the reverse exceptionalist rules surveyed in Part IIB that depart from the norms of private contract law by imposing special obligations on the government, and truly exceptionalist doctrines that serve primarily to limit the liability or obligations of the government arising out of contracting. As explained above, however, most of the departures from the norms of private contracting that pertain to contract formation fall into the former category of reverse exceptionalism.

Still, there are some significant genuinely exceptionalist elements to the law of federal public contract formation in the United States that should be noted here briefly in order to give the reader an accurate overall picture of the scope and incidence of exceptionalism in United States public contract law. These include:

- the Anti-Deficiency Act, ${ }^{47}$ and Appropriations Clause, ${ }^{48}$ which protect the United States from entering into a binding contract absent a covering appropriation made by Congress; ${ }^{49}$ and

- the regulatory requirement that, even without offering a binding option contract to the government, a bid unsupported by consideration nonetheless ordinarily is binding and

${ }^{47} 31$ U.S.C. $\S 1341$

${ }^{48}$ United States Const., Art. I, Sec. 9, cl. 7.

${ }^{49}$ See Hercules, Inc. v. United States, 516 U.S. 417, 426-427 (1996) (re: Anti-Deficiency Act); Office of Personnel Management v. Richmond, 496 U.S. 414, 424-434 (1990)(re: Appropriations Clause); Schism v. United States, 316 F.3d 1259, 1284 (2002), cert. denied, 539 U.S. 910 (2003) (dictum re: Anti-Deficiency Act). 
may not ordinarily be withdrawn after the date fixed for opening of bids. The government may accept such a bid, despite a purported withdrawal, creating a binding contract, and hold the contractor liable for default if it declines to perform. ${ }^{50}$

In addition to these doctrines that are characteristically part of the law of public contract formation, there are significant exceptionalist rules that affect both issues of contract formation and disputes arising out of contract performance. Salient examples are the interrelated doctrines that apparent authority does not operate against the United States and that the United States is generally immune from the operation of equitable estoppel. ${ }^{51}$ These rules may be invoked to bar recognition of a contract ab initio where it is entered by a person who lacks actual authority. ${ }^{52}$ Or they may be invoked to bar recognition of a binding contract where a contract is entered in violation of applicable legal requirements. ${ }^{53}$ But they also may be invoked in a contract performance dispute context to bar modification of the terms of a government contract where the officer alleged to have agreed to the modification lacked the requisite authority or was acting in

\footnotetext{
${ }^{50}$ See, e.g. Refining Associates, Inc. v. United States, 124 Ct.Cl. 115 (1953); 48 C.F.R. $\S 14.303(\mathrm{a}) ; 48$ C.F.R. $\S 14.304(\mathrm{a}),(\mathrm{b})(1),(\mathrm{e}),(\mathrm{f})$.

${ }^{51}$ Office of Personnel Management v. Richmond, 496 U.S. 414 (1990) (immunity from equitable estoppel); FCIC v. Merrill, 332 U.S. 380 (1947) (same); compare, e.g. Gordon Woodroffe Corp. v. United States, 104 F. Supp. 984, 988 (Ct. Cl. 1952)(U.S. not bound by agent acting without possessing actual authority), with id. at 988-989 (Madden, J., dissenting) (U.S. should be bound by act done with apparent authority).

${ }^{52}$ E.g. Gordon Woodroffe, 104 F. Supp. at 988.

${ }^{53}$ Office of Personnel Management v. Richmond, 496 U.S. 414 (1990); Hercules, Inc. v. United States, 516 U.S. 417, 426-427 (1996).
} 
violation of applicable legal requirements. ${ }^{54}$

Another example of an exceptionalist departures from the norms of private contracting that affects both contract formation and contract performance and disputes pertaining thereto is the heavy reliance on open-ended contractual vehicles such as task order contracting and other forms of Indefinite Delivery- Indefinite Quantity ("IDIQ") contracts, including the Multiple Award and Single Award Schedules under the Federal Supply Schedules, to meet many of the procurement needs of federal agencies today. ${ }^{55}$ These special contract vehicles can present formation issues, because, at least in the case of the Multiple Award Schedules, private law norms for consideration requisite to establish a binding contract do not appear to satisfied, yet a private contractor is bound by its offer to supply scheduled items on the basis for which it is scheduled. But the primary effect of such an award is to enable to government to call upon a contractor, essentially at its unilateral discretion, to provide a level of service or goods, determined unilaterally, on a schedule that is determined unilaterally. Thus these could be viewed as departures from the norms of private contracting with respect to both the formation and the performance of a contractual undertaking. The dramatic potential for the use and abuse of such contract vehicles has been made much more visible to the public by the heavy reliance of

${ }^{54}$ General Electric Co. v. United States, 412 F.2d 1215, 1218 \& n.4 (Ct. Cl. 1969).

${ }^{55} \mathrm{See}$ John Cibinic \& Ralph C. Nash, Jr., Formation of Government Contracts (George Washington Univ. 3d ed. 1998) (hereinafter "Formation"), at 1238-1252; Ralph C. Nash, Jr., Steven L. Schooner \& Karen R. O’Brien, The government Contracts Reference BOoK (George Washington Univ. 2d ed. 1998) (hereinafter "Government Contracts REFERENCE BOOK"), at 243-244 ("Federal Supply Schedules"), 295-296 ("Indefinite-Delivery Contract" and "Indefinite-Quantity Contract"), 355-365 ("Multiple Award Schedule"), 506-507 ("Task Order" and "Task Order Contract"); Steven L. Schooner, Fear of Oversight: The Fundamental Failure of Businesslike Government, 50 AMER. U. L. REV. 627, (2001). 
the United States on such instruments in the Iraq War of 2003-2004 and the rebuilding of Iraq. ${ }^{56}$

An additional important example of exceptionalism in the law of public contract formation arguably is found in the deferential standard of review reflected in the Scanwell/Steinthal doctrine, which allowed for judicial consideration of bid protests arising out of the award of a federal government contract. ${ }^{57}$ Adoption of this deferential approach was considered appropriate because of the highly technical nature of the procurement policy issues involved, as well as the complexity of the pertinent legal structure, and the greater expertise of agency procurement officials, and of the General Accounting Office (an available nonjudicial protest forum), as compared to that of a reviewing court, in addressing these technical matters. ${ }^{58}$ As is noted in Part IIIC, this policy of deferential review is applied with special strength in the context of military procurement. ${ }^{59}$ Of course, one might question whether the label exceptionalism fits properly here, as the procurement choices of non-governmental purchasers ordinarily would not be subject to any judicial review. Subjection of the government's

${ }^{56}$ Stephen L. Schooner, \{Abu Ghraib piece, forthcoming _ _ Stanford Law and Policy J. (2004)\}; Christopher Yukins \& Mohab Khattab, Iraqi Construction Awards Should Not be Immune from Review, 80 Federal Contracts Report No. 18, 512-516 (Nov. 18, 2003); L. Elaine Halchin, The Coalition Provisional Authority (CPA): Origin, Characteristics, AND Institutional Authorities (Congressional Research Service, April 29, 2004), at 15-23.

${ }^{57}$ M. Steinthal \& Co. v. Seamans, 455 F.2d 1289, 1298-1299, 1300-1306 (D.C. Cir. 1971); Shoals American Industries, Inc. v. United States, 877 F.2d 883, 888-889 (11 ${ }^{\text {th }}$ Cir. 1989). This standard of review, based on the federal Administrative Procedure Act, 5 U.S.C. § 706, now has been made applicable to bid protests heard in the Court of Federal Claims. 28 U.S.C. $\S$ 1491(b)(1) \& (4). See also infra TAN ___ _ (regarding the especially deferential standard of review to be applied in bid protests arising out of military procurement).

${ }^{58} 455$ F.2d at 1300-1306.

${ }^{59}$ See infra TAN 
procurement decisions to judicial review, in and of itself, may properly be considered a manifestation of reverse exceptionalism, which burdens the government and provides rights to a would-be contractor. Adoption of the deferential standard of review for such judicial review proceedings may best be viewed, then, as an accommodation between the reverse exceptionalist values served by giving disappointed offerors the right to maintain a bid protest, and the exceptionalist policies that serve the needs of the government to be free of harmful and intrusive judicial second-guessing of its procurement policy decisions.

Other significant features of the federal procurement law governing contract formation, may likewise be best understood as seeking to reconcile the special obligations that the government bears in the contract formation process with exceptionalist policies and concerns. Among these are rules and procedures superimposed upon the basic requirements of public contract formation (themselves designed to assure transparently and competitive procurement for the benefit of contractors and the public, imposing obligations on government agencies) that are designed to afford procuring agencies additional flexibility in securing these objectives.

Salient in that category is the development of the process of competitive negotiation as an alternative to sealed bidding as a procedure for undertaking open competitive procurement. ${ }^{60}$ Competitive negotiation is designed to allow transparent competitive procurement that nonetheless affords agencies discretion to secure "best value" defined in terms of multiple criteria, including qualitative measures in addition to price measures, rather than simply choosing

\footnotetext{
${ }^{60}$ See Cibinic \& Nash, Formation, supra note 55, at 709-967; Nash, Schooner \& O’Brien, Government Contracts Reference Book, supra note 55, at 107-108 ("Competitive Proposals," and "Competitive Range.")
} 
the lowest price bid. ${ }^{61}$

Another significant accommodationist doctrine with this character is the development of the cost-reimbursement contract. ${ }^{62}$ Cost reimbursement contracts enable the government to contract on flexible financial terms that would, to say the least, be unusual in private contracts. They are therefore appropriately regarded as exceptionalist accommodations. Essentially, the government agrees in advance to pay the contractor its audited cost of performance, plus a profit increment. Use of such flexible financial terms serves to allocate to the government the unacceptably high risk associated with the performance of certain government contracts, which call for cutting edge performances of unknown difficulty. By allocating the risk that performance will be unexpectedly difficult and expensive to the government, the government seeks to induce contractors to make offers on work where the risks are too great to bid on a fixedprice basis, or where those offers would otherwise necessitate so large a risk premium built into the fixed price as to make the contract more expensive than its actuarial cost.

In addition to the foregoing, there are public procurement-related doctrines in the United States that defy ready categorization as bearing directly on contract formation, contract performance, or on both, that nonetheless are marked by departure from the norms that govern private contracts. These rules also are not so readily classifiable as either exceptionalist in the pure sense defined here, or reverse exceptionalist in their operation. A distinguishing feature of

${ }^{61} 10$ U.S.C. $\S 2305(a) \&(b)(4)$ (criteria and procedures for awards in competitive negotiation).

${ }^{62}$ John Cibinic \& Ralph C. Nash, Jr., Cost Reimbursement Contracting (George Washington Univ. 2d ed. 1993), passim; Nash, Schooner \& O'Brien, GOVERnMENT CONTRACTS REFERENCE BOOK, supra note 55, at 146-147. 
this group of government contract doctrines is that they bear most directly on the rights and immunities of government contractors as against parties other than the federal government.

Perhaps the leading example of such a rule, is the "government contractor defense" doctrine established by Boyle v. United Technologies Corp. ${ }^{63}$ Boyle, which grows ultimately out of the choice of law principles articulated in Clearfield Trust ${ }^{64}$ establishes judge-made, federal common law defense for certain federal government contractors, applicable to state tort law claims brought against the contractor. Boyle holds that

liability for ... defects in military equipment cannot be imposed, pursuant to state law, when (1) the United States approved reasonably precise specifications; (2) the equipment conformed to those specifications; and (3) the [contractor] warned the United States about dangers in the use of the equipment that were know to the [contractor] but not to the United States. ${ }^{65}$

Note as well, that this departure from the tort norms that would surround an ordinarily private contract arose in the context of military procurement and draws much of its rationale from the policy considerations that discourage courts aggressive second-guessing of military procurement decisions. ${ }^{66}$ Note as well that the rationale for extending immunity to a contractor in this situation is based on the desire to protect the interests and prerogatives of the federal government. ${ }^{67}$ In that sense the government contractor defense fits properly within the bounds of the exceptionalist approach as defined here.

\footnotetext{
${ }^{63} 487$ U.S. 500 (1988).

${ }^{64}$ See supra TAN

${ }^{65} 487$ U.S. at 512.

${ }^{66}$ See infra TAN

${ }^{67} 487$ U.S. at 504-509.
} 
A final example of this kind of exceptionalism is the derivative regulatory immunity (against state regulation) that extends to federal government contractors where the imposition of state regulation on the federal government contractor would interfere with federal procurement policies. ${ }^{68}$ Plainly, in this case as well, the purpose of extending immunity to the contractor is to protect the interests and policies of the federal government from state interference. ${ }^{69}$

\section{The Incidence of Exceptionalism}

This Article has now defined the phenomenon of exceptionalism in public procurement law more precisely, distinguishing it from the reverse exceptionalism that characterizes much of the United States law of government contract formation. The Article has also surveyed the waterfront of significant examples of exceptionalism in settings pertaining to government contract formation and government contract performance, as well as doctrines that cut across this categorization, or which exists outside its categories. Based on this comprehensive survey, it is now possible to assess the locus of the phenomenon of exceptionalism within the United States law of public contracts.

True exceptionalism is primarily manifested in the law of public contract performance, and only secondarily in the law of federal government contract formation and elsewhere in government contracts law. This is significant, inter alia, for comparative law purposes because it

${ }^{68}$ See Paul v. United States, 371 U.S. 245 (1963) (federal milk supplier is exempt from state minimum price laws because they would block the federal policy to secure the most advantageous price through unconstrained price competition).

${ }^{69} 371$ U.S. at $250-255$. 
Centrality of U.S. Military Procurement (Draft 10/17/04), page 42

means that United States public procurement law is most strikingly exceptionalist with regard to aspects of the procurement law system, broadly defined, that are not even considered an integral part of the public procurement law system of the European Community or the systems of many European and civil law countries, including, for instance, those of the United Kingdom and Germany. Although a closer examination of the impact of the doctrines associated with "administrative contracts" in many civil law nations may ultimately significantly qualify this conclusion, the pattern discerned here suggests a strong contrast between the procurement law regime of the United States and those of many other nations. In sum, where the United States emphasizes "exceptionalism" in the law of public contract performance, the dominant European law tendency emphasizes "congruence." In Part III of this Article we propose and evaluate an explanation for this divergence: the unusually strong role that military procurement has played in the development of the United States public procurement system and legal doctrine.

\section{Exceptionalism and the Centrality of Military Procurement}

If we review the examples of exceptionalism noted in the previous section of this paper, and examine the genesis of these exceptional rules, including both examples among the rules that govern government contract performance and examples from the law of public contract formation, it is striking how often the leading cases involve military procurement. Military procurement disputes played a crucial role in the development of United States public procurement law as midwife facilitating the birth of a highly exceptionalist regime of public procurement law. 
Centrality of U.S. Military Procurement (Draft 10/17/04), page 43

In this section of this paper we initially address a significant question about the method for presenting and demonstrating the power of this hypothesis. Next comes a brief historical overview designed to confirm the centrality of military procurement throughout the history of the United States' procurement system. Finally, we turn to the key point, the evidence of the key role played by military procurement in the emergence of an exceptionalist-oriented body of public procurement law.

\section{A. Comparative Analysis and a Note on Causation, Coincidence and Methodology}

Perhaps this is as good a juncture as any to consider an important point that bears importantly on any assessment of the causal hypothesis explored here: that military procurement - and disputes and policy controversies arising therefrom - played a distinctive and important role in the development of the exceptionalist thread in the United States' law of public procurement. To be sure, a comprehensive history of government procurement in the United States by James Nagle confidently asserts at the very threshold that "[m]ilitary contracts command center stage in any history of government procurement." ${ }^{70}$ Read in context, of course, it is reasonably clear that Jim Nagle's assertion is meant to apply only to the history of procurement in the United States, which is, after all, the subject of his book. Of course, it is also true that, in the United States, regulation of defense and military procurement historically has been at the center of development of the rules and procedures for procurement. ${ }^{71}$ The extension

\footnotetext{
${ }^{70}$ James F. Nagle, A History of Government Contracting (George Washington University Press, 2d ed. 1999), 2.

${ }^{71}$ This is documented in the next two sections of this Article, Parts IIIB and IIIC.
} 
of a comprehensive framework for transparent regulated public procurement to most civilian procurement, was in the United States, a comparatively recent innovation (traceable to 1965). ${ }^{72}$ By contrast, it is apparent that differing approaches have been taken in and within the European Union. For instance, Martin Trybus reported in his 1998 survey that in the European Union "hard defence equipment" was excluded - at least in practice - from the Community's internal market and that accordingly there is no single market for hard defence equipment within the EU and national governments still assume total control over this market. ${ }^{73}$ Moreover, he reports a

\footnotetext{
${ }^{72}$ Andrus v. Glover Constr. Co., 446 U.S. 608, 614-615 (1980); Motor Coach Indus., Inc. v. Dole, 725 F.2d 958, $966 \&$ n.8 ( $4^{\text {th }}$ Cir. 1984).

${ }^{73}$ Martin Trybus, "National Models for the Regulation of the Acquisition of Armaments: Toward a European Defence Procurement Code," in Sue Arrowsmith \& Arwel Davies, eds., Public Procurement: Global Revolution (Kluwer Law Int'1, 1998), 71. See also \{Martin Trybus European Defence Procurement Law: National and International Models for a Liberalised Defence Procurement Market (Kluwer Law Int'1, 1999), Ch. 1; Arie Reich, International Public Procurement LaW (Kluwer 1999), 200-201 (reporting some progress in extending EU Directives to cover non-military specific goods bought for military purposes; but otherwise military procurement remains exempt from the EU framework).

Trybus notes that hard defense material was excluded from the application of the EC Treaty and the specialized EC procurement directives, at least in practice, by the broad interpretation given the armaments exemption of Article 296(1)(b) of the EC Treaty by the Member States. This broad interpretation of the Treaty's armaments exception treated that provision as a categorical exclusion of all hard defense material from the application of the Treaty, dispensing with any requirement that application of the exemption be invoked and justified in individual cases. However, since the judgment of the European Court of Justice in \{Case C-414/97, Commission v. Spain, [ ] ECR___ \}, it is clear that Article 296(1)(b) of the EC Treaty will not be interpreted as a such a broad categorical exemption, and will need to be specifically invoked and its application justified by the Member State seeking to bring itself within application of the exception in a particular procurement. \{Martin Trybus, "Procurement for the Armed Forces: Balancing National Security with the Internal Market," _ European Law Review __ (2000). $\}$ Although the broad interpretation of the armaments exclusion apparently continues to prevail in the practice of European Community Member States, the wording of the armaments exclusion in the new European Community Public Procurement Directive appears to accommodate the narrower interpretation given the Treaty exclusion in Commission v. Spain. \{quote/cite-Trybus?\}
} 
striking diversity of approaches among major EU nations in this regard, ranging from France, which applied a well-developed regulated approach to defense procurement, to Germany, which applies a "formal procurement regime with detailed rules" to defense procurement, but which treats these rules as "not generally enforceable," all the way to the United Kingdom, which, he reports, follows an unregulated approach to defense procurement in which "defence contracts are not awarded according to fixed and legally binding contract award procedures." ${ }^{, 74}$ The World Trade Organization's Government Procurement Agreement provides in Article XXIII(1) a broad right to exclude military procurement from the operation of that regime. ${ }^{75}$ So regulation of military procurement is scarcely the norm in the advanced western economies. Similarly, developing nations and those with economies somewhere in the transition from socialism to a freer market often choose to exclude military procurement from the coverage of newly adopted procurement law regimes as they move toward compliance with emerging international norms for

\footnotetext{
${ }^{74} I d$. at 76, 80, 82. See \{Laurence Folliot-Lalliot, French Public Contracts, forthcoming West's International Government Contractor (200x)\} Part I, Chap. 1, Sec. 6 F (regarding provisions of the new French Public Procurement Code permitting some defense contracts to be excluded from the operation of the French Procurement Code where it is necessary to keep the contract secret in the national interest; still coverage of military procurement under the Code is the default norm).

$75 \quad$ Nothing in this Agreement shall be construed to prevent any party from taking any action or not disclosing any information which it considers necessary for the protection of its essential security interests relating to the procurement of arms, ammunition or war materials, or to procurement indispensable for national security or for national defence purposes.
}

Note the phrasing, which allows each government to be the judge of its own claim that it is necessary for security or defense reasons to exempt such procurement from the operation of the multilateral open regime created by the GPA. This language tracks a model employed, as well, in other international agreements, including the GATT, GATS and TRIPS agreements. \{Citations.\} 
Centrality of U.S. Military Procurement (Draft 10/17/04), page 46

transparent and competitive procurement. ${ }^{76}$ Indeed the UNCITRAL Model Procurement Law allows nations to exempt procurement affecting national security or defense from its requirements for competitive regulated procurement. ${ }^{77}$ Thus, despite the sometimes United States-centric perspective of legal observers on this, western, side of the Atlantic, it should not be assumed that the creation of a procurement law regime on a template designed to accommodate military procurement somehow reflects a universal constant or an international norm.

Still, even if the development of a procurement law that grew up around the needs of military procurement is somewhat remarkable, viewed in comparative and historical perspective, it is necessary to consider the alternative possibility that the salience of military procurement in the cases that establish and define the exceptionalist character of much of United States' public

${ }^{76}$ The recently enacted Chinese Procurement Law provides in pertinent part:

Article 85: Urgent procurements carried out in the case of force majeure, including serious natural disasters and other unavoidable situations, as well as procurements involving state security and secrets shall not be governed by this law.

Article 86: The laws and regulations for military procurement shall be separately formulated by the Military Commission of the Central Committee of the Chinese Communist Party.

See, also Daniel Mitterhoff, Background Report on the Reform of China's Public Procurement Regime (China-Mekong Law Center 2001), pp. 2, 30 (regarding Arts. 71 \& 72 of Oct. 2000 draft of proposed Government Procurement Law of the People's Republic of China); J. Schwartz, Learning from the United States' Procurement Law Experience, 11 Pub. Proc. L. REV. 115, 122-123 (2002).

${ }^{77}$ UNCITRAL Article 1(2); see Robert R. Hunja, "The UNCITRAL Model Law on Procurement of Goods, Construction and Services and Its Impact on Procurement Reform," in Sue Arrowsmith \& Arwel Davies, Public Procurement: Global Revolution, supra note , at 97, 99. Robert Hunja's chapter is presented by Arrowsmith and Davies in the section of their book devoted to public procurement reform in developing and transition economies. 
procurement law regime is largely a coincidence or historical artifact, rather than a distinctive cause of the emergence of that exceptionalist tendency in the procurement law of the United States. Indeed, precisely because so much of the procurement in the early years of the United States' history was military procurement, disputes arising in those cases were disproportionately likely to have become the vehicle for deciding points of law that might equally apply in nonmilitary contexts. This might well have been so even if the fact that the test cases arose from military procurement made no other difference to the outcome of the cases. The methodological difficulty is compounded by the fact that there plainly is no direct way to test how the character of United States procurement law might have emerged differently had it not engrossed military procurement within its coverage.

As previously indicated, one way of evaluating the alternative "coincidence" hypothesis would be to examine the procurement law of other nations to try to confirm the causal connection between coverage of military procurement in a nation's procurement law regime, and the tendency to reflect what is labeled here as an exceptionalist approach. Understandably, a full comparative law analysis that could confirm or disprove my hypothesis in this manner is well beyond the scope of the present paper. On the other hand, it is my hope that, armed with the model and the basis for comparison established here, others will undertake, either on a country specific, or a multi-nation basis, the examination suggested here of the link between regulation of military procurement and the emergence of a strong exceptionalist tendency within a particular procurement law regime. Thus, ultimately, the materials necessary for undertaking a rigorous, powerful and comprehensive comparative analysis on this point will be assembled. The author 
looks forward to returning to this subject as others have added to the corpus of materials available for examining this hypothesis in comparative perspective.

For the present, however, the task of this article is pursued differently. The method employed here, which focuses on the internal analysis of the operation and history of the United States' procurement law regime, is to demonstrate through careful analysis of seminal cases in which exceptionalist doctrines emerged, the important role played by military procurement and its regulation in the United States. More specifically, to counter the alternative "coincidence" hypothesis noted above, it will be helpful to demonstrate that the exceptionalist doctrines were developed, to a strikingly disproportionate degree, in cases involving military procurement. But it will be equally, if not more important, to demonstrate that the military procurement context and the compelling special policies that arise in that context contributed powerfully to the rationales given for the decisions rendered in developing those exceptionalist doctrines. That is the challenge undertaken here.

\section{B. Centrality of Military Procurement in the United States}

Just as this work cannot provide a comprehensive account of all of the doctrinal contours of United States public procurement law without inflating into the proportions of a treatise, so too, it cannot stand on its own as a history of the development of the public procurement system in the United States. ${ }^{78}$ Fortunately for the author, and for the reader, Jim Nagle has provided us with a fine history of that system, updated in 1999, that serves us well, in drawing conclusions

\footnotetext{
${ }^{78}$ See supra TAN
} 
Centrality of U.S. Military Procurement (Draft 10/17/04), page 49

about the overall character of the United States' procurement system and the role of military procurement therein. ${ }^{79}$

As Nagle has concluded, "[m]ilitary contracts command central stage in any history of government procurement" in the United States. ${ }^{80}$ And military contracting does indeed command the center of the stage in his valuable history of United States federal public contracting. The chapters of his work are structured to a substantial degree around successive eras of combat, commencing in the pre-Revolutionary era with the French and Indian War, moving on the Revolutionary War, followed by the War of 1812, the Civil War, the Spanish-American War and World War I, and on to World War II, and finally to the post-war era. Nor are these just handy chronological units. An immersion in the historical materials such as that undertaken by Nagle reveals that the war eras thrust striking and new challenges on the United States that produced innovative responses in the management and regulation of public procurement. Some of the issues changed over time in different eras, but it remained true that military procurement was typically the main engine that drove forward the development of what gradually became a sophisticated system of regulated public procurement. In the early history of the United States, moreover, military procurement formed the heart of public procurement. It also drove the beginnings of efforts systematically to regulate public procurement and the earliest efforts to begin to create a norm of open competition and transparency. At each successive stage of the development of federal government contracting practice and of its regulation, military

\footnotetext{
${ }^{79}$ Nagle, supra note 24.

${ }^{80}$ Nagle, supra note 24 , at 2.
} 
procurement was at the forefront of challenge and of innovation.

Nor was the salience of military procurement merely a historical constant. Rather, as Nagle demonstrates, the themes, debates, and problems that recur throughout the history of United States public procurement, are predominantly ones that emerge characteristically from military procurement, or which emphasize its role. These include, significantly:

- the mixed blessings associated with the emergence and power of a "military-industrial complex,"

- the problems of "profiteering " and excessive profits in the shortage conditions of war time,

- the debates over the nationalization alternative to government contracting that take on particular force in the presence of war time profit opportunities for contractors,

- the ethical challenges aggravated by "revolving doors" and blending of private and public interests and roles, between government and its contractors in private industry, which swing all the more rapidly in war time and in its aftermath,

- and, finally, the special need for and the special difficulty of achieving meaningful competition when faced with the exigencies of mobilization for war or comparable national crises. ${ }^{81}$

Nagle's survey also shows that military contracting has been at the heart of the procedural story of government contracting over the years. He asserts: "Much of the country's contracting history has been spent trying to find the best combination of three factors: the right contracting

\footnotetext{
${ }^{81}$ Nagle, supra note 24 at 5-7
} 
apparatus, the right government-contractor relationship, and the correct contract form itself." ${ }^{\prime 2}$ The history he recounts, selectively noted below, shows that military procurement typically was at the forefront of development in each of these areas. In sum, at every stage of public procurement history, military procurement was at the heart of the most contentious issues as well as the most innovative solutions.

Of course, Nagle acknowledges that "[f]ocusing" entirely "on wars and the military would overlook a tremendous source of history." ${ }^{\circ 3}$ Specifically, Nagle acknowledges that in different eras of United States history civilian agencies engaged in development of essential new infrastructure such as the Post Office Department and, later, the Bureau of Reclamation with its program of dam construction, contributed substantially to the practice of government contracting. ${ }^{84}$ Still, it would require a willful blindness to the main currents of United States history to miss the fact that military and defense contracting has played the central role in development of both the United States system of public procurement and the development of a regulatory structure therefor. It is striking, moreover, that even the civilian examples offered by Nagle generally reflect critical and extraordinary national efforts, essential to the development of the new nation, and to further progress in succeeding eras, that confronted the United States with challenges (and opportunities for technical, managerial, and legal innovation) comparable in scope and importance to those presented by the exigencies of war time. Thus in recent eras we

\footnotetext{
${ }^{82} I d$. at $7-8$.

${ }^{83} I d$. at 4.

${ }^{84}$ See, e.g. id. at 4-5, 57-60, 151-163, 168-170, 361-377.
} 
can think of the challenge of getting astronauts to stand on the moon, or some of the recent national security tasks arising in the wake of the terrorist attack of 9/11/2001. (The latter, of course, may in fact be considered, a part of, rather than a counter to, the pre-eminence of military and defense tasks in the development of public procurement in the United States.) In summary overview then, the largest part of the story of United States procurement and public procurement law then, has been the development of military procurement and a legal framework for military procurement, followed by the gradual extension of the norms of military public contracting to the entire field of federal public contracting.

Fortunately, the propositions suggested here about the centrality of military procurement in the development of the United States' system are borne out by common sense and common knowledge. They may, indeed, strike some readers as too obvious to warrant discussion or elaborate proof. In any event, any comprehensive historical demonstration of the central role played by military procurement in the development of the United States' procurement system is necessarily beyond the scope of this article, or any article. ${ }^{85}$ Relying heavily on Nagle's useful treatment, however, we can confidently conclude that military procurement has played a critical role in the development and evolution of the federal public procurement regime of in the United States. Moreover, this point is tellingly corroborated in the next section of this Article, which surveys the role of military procurement in the emergence of significant exceptionalist doctrines of procurement law.

${ }^{85}$ Nagle himself emphasizes that his history, which weighs in at over 600 pages, is itself the product of the exercise of striking "selectivity." Id. at 8-9. 


\section{Military Procurement and Exceptionalism}

In Part II of this Article, the author surveyed the public procurement law of the United States in order to more rigorously to define and demonstrate the strongly exceptionalist character of that body of law. It was demonstrted, as well, that exceptionalism, as it has been defined here, is significantly, but not exclusively, concentrated in the law governing performance of federal public contracts as opposed to the law of federal government contract formation. In the process of carrying out that doctrinal survey much evidence was adduced that will support the other branch of the author's thesis: that the salience of military procurement in the development of the United States public procurement law regime has been a very substantial cause of the emergence of the exceptionalist flavor of that body of procurement law. As is more systematically demonstrated in this last portion of this Article, the strikingly importance of the military role is reflected in exceptionalist doctrines pertaining to contract formation as well as those pertaining to contract performance, and also in some doctrines that affect both areas or which defy ready categorization into either category.

As in Part II of this Article, limitations of space make it necessary to be selective here. This can be neither a comprehensive historical account, nor a complete doctrinal survey of United States public procurement law. As a result, fuller accounts are offered of the development of some of the most significant exceptionalist rules of United States public procurement law, designed to test the hypothesis that military procurement has been a major driver of the exceptionalist character of the system. Some of the most telling examples are considered in this fashion, with other exceptionalist features of this body of law treated more 
summarily. Although this survey generally bears out the claim made here about the critical importance of the inclusion of military procurement in explaining the exceptionalist character of the body of United States public procurement law, some of the examples considered demonstrate that the true picture is somewhat more complex. The willingness of United States courts and legislators to recognize overriding considerations that justify departures from the norm of congruence generally, and from specific rules of private contract law, is strongly correlated with the role of military procurement. Recognition of overriding prerogatives for the sovereign as contractor has been accentuated and potentiated by the consideration of disputes and policy issues arising in the setting of military procurement. Although military procurement has thus catalyzed the emergence of exceptionalism in United States public procurement law, the selective survey presented here also demonstrates that recognition of special sovereign prerogatives has not be limited to the sphere of military procurement. In some instances, such as the termination for convenience doctrine, the special latitude initially granted to the government in a military setting has come to transcend that setting. In other instances, such as the sovereign acts and unmistakability doctrine, the compelling needs of military activities illustrate, but do not limit or fully define the scope of the overriding sovereign priorities whose recognition produced strikingly exceptionalist rules for federal public procurement.

Of course, the selective approach taken here invites other scholars to flesh out the work begun here with more detailed study of additional exceptionalist elements in the body of United States public procurement law, as well as to search further for congruence-oriented elements of the corpus of public procurement law that emerged despite the influence of military procurement 
Centrality of U.S. Military Procurement (Draft 10/17/04), page 55

on the system. In addition, of course, as previously noted, it is hoped that the present study will encourage other scholars to test the hypothesis articulated here against the history and doctrine of government procurement law regimes in other nations and in transnational legal orders.

\section{Termination for Convenience}

The development of the United States' government's broad power of termination for convenience over its public contracts offers a paradigmatic example of the role that military procurement has played in the emergence of the strongly exceptionalist elements in the United States' public procurement law. ${ }^{86}$ Our legal story begins with one of the relatively unusual forays of the Supreme Court of the United States into the area of public contracts and related legal issues, the 1875 decision of the Court in United States v. Corliss Steam-Engine Co. ${ }^{87}$

In Corliss, the United States Navy Department had entered into contracts with the plaintiff during the Civil War for the manufacture of certain machinery that the Navy expected to employ in the prosecution of the war effort. As the Court tells it, "[ $\mathrm{t}]$ he completion of the

\footnotetext{
${ }^{86}$ See supra note ___ and accompanying text.
}

${ }^{87} 91$ U.S. 321 (1875). It appears that earlier in the development of federal public contracts law such cases were more common than they have become in recent years and played a more significant role on the Supreme Court docket. The Supreme Court thus played a more central and less interstitial role in the development of public contract law in this early formative period.

The author hesitates even to label Corliss Steam-Engine Co. a case about "public contracts law" proper, for the lawfulness of the practice of termination for convenience was assumed, rather than decided in the case, strictly speaking; the questions squarely presented in Corliss Steam-Engine Co. related only to the authority of federal government officials to enter into binding contracts on behalf of the United States. Still the language of the case is so sweeping that the case has assumed precedential significance, and is widely regarded as establishing the lawfulness of a broad reservation authority to terminate a federal public contract for the convenience of the government, at least in a military setting. 
Centrality of U.S. Military Procurement (Draft 10/17/04), page 56

machinery contracted for having become unnecessary from the termination of the war, the secretary [of the Navy], in the exercise of his judgment, under the advice of a board of naval advisers, suspended the work." ${ }^{" 88}$ Although the Court used the term suspension, there was nothing temporary about the administrative action terminating a contract that by then had been partially performed by the contractor. The contractor did not formally contest the lawfulness of the termination, eschewing any argument that the termination effected a breach of its original contract, but instead offered the government alternative proposals to settle the obligation of the government for the work that had been done. ${ }^{89}$ The government accepted one of the contractor's suggestions for terms of a settlement and agreed to the sum to be paid the contractor. However, because the Navy did not then have sufficient appropriated funds on hand to pay the full amount of the settlement agreement, it stipulated therein that only partial payment would be made immediately upon delivery of the partially completed equipment, with further payments to be made when, and only if, further appropriations covering this obligation became available from Congress. $^{90}$

\section{${ }^{88} \mathrm{Id}$. at 323 .}

${ }^{89}$ The contractor offered either to keep the partially manufactured machinery and a payment of $\$ 150,000$, or to deliver the incomplete equipment to the government coupled with a payment to it of $\$ 259,068$. Id . at 321 .

${ }^{90} I d$. at 322. Note that this stipulation, which follows the model of what today would be called a "funds available," "funds availability" or "availability of funds" clause generally is necessary, even today, whenever the funds called for by a contract exceed available appropriations, to avoid a violation of the Anti-Deficiency Act, 31 U.S.C. $\S 1341(\mathrm{a})(1)(\mathrm{B})$. See, e.g. C.H. Leavell \& Co. v. United States, 530 F.2d 878 (Ct. Cl. 1976) (interpreting a funds availability clause); 48 C.F.R. $\S 32.705-1$ (a) (mandating Availability of Funds Clause); 48 C.F.R. $\S 52.232-18$ (prescribing language for Availability of Funds Clause.)

Even absent the clause from a contract, the Appropriations Clause of the United States 
The machinery was delivered in accordance with this settlement agreement, but the contractor found it necessary to sue the government for damages in the Court of Claims to recover the compensation owing under the settlement agreement ${ }^{91}$ The issue raised on appeal before the Supreme Court was whether the Secretary of the Navy had the requisite authority to enter into a binding contract of settlement with the contractor in this situation. Arguing a position that would have disserved the government's long-run interests in establishing its procurement authority and general power to contract, the government defended its refusal to pay, asserting that authority was lacking to enter into a binding agreement of this kind. Fortunately, the government lost this battle, thereby winning "the war" and establishing both the broad authority of executive branch agencies to enter into binding contracts, for procurement as well as for settlement of procurement disputes, as well as the legitimacy of the practice of termination for

Constitution, Art. I, Sec. 9, cl.7, would raise a bar to payment not covered by a valid and applicable statutory appropriation. Office of Personnel Management v. Richmond, 496 U.S. 414, 424-434 (1990). However, if funds did not become available and such a clause were absent from the contract, the United States would be left in the posture of breaching its contract with no remedy available to the contractor. The funds availability clause thus makes transparent the government's exceptional defense to payment on its contracts arising from the Appropriations Clause by warning the contractor of the salient pre-condition that limits the government's undertaking to pay its obligation.

Of course, one might think that the very idea of conditioning the government's undertaking to pay on the discretionary decision of a future Congress to appropriate funds would render the contract illusory, but this has never been the law. As a private contracting party almost certainly could not so condition its obligation to pay so broadly without rendering its contract unenforceable, the complex of doctrines associated with the Appropriations Clause, the Anti-Deficiency Act, and Funds Availability Clauses reflects a significant exceptionalist element in federal public contracts law. It affects both the formation and performance of such federal public contracts.

${ }^{91}$ Corliss Steam-Engine Co., 91 U.S. at 321. Apparently, moreover, the necessary funds were appropriated because the government did not defend its non-payment by relying on the Funds Availability Clause that had been inserted in the settlement agreement. 
convenience, at least in this military context.

The Court's language is emphatic, and unqualified, making clear the importance of the military context to the result reached. In deciding the question of authority to contract, the Court noted both the generic grant of authority to the Navy Department to procure naval stores and equipment, and the more specific grants of statutory authority and legislative appropriations for making such purchases specifically for the prosecution of the Civil War to put down "the rebellion." ${ }^{92}$ This authority was vested in the Secretary of the Navy, moreover, under the direction of the President, and it extended not only to "enter[ing]" into procurement "contracts for public service," initially, but also to suspending such contracts, where appropriate, and entering into binding contracts of settlement resulting from such terminations: ${ }^{93}$ "As, in making the original contracts, he must agree upon the compensation to be made for their entire performance, it would seem, that, when those contracts are suspended by him, he must be equally authorized to agree upon the compensation for their partial performance. ${ }^{94}$ It seems fair to conclude that the military context, and the obvious necessity for this kind of exercise of the contracting power, helped to persuade the Court that the statutory power to contract existed here. The Court explained:

the discharge of the duty devolving on the secretary [of the Navy] necessarily requires him to enter into numerous contracts for public service; and the power to suspend work contracted for, whether in the construction, armament, or equipment of vessels of war, when from any cause the public interest requires such suspension, must necessarily rest

\footnotetext{
${ }^{92} I d$. at $322,323$.

${ }^{93} I d$. at 322 .

${ }^{94} I d$. at 322-323.
} 
with him. ${ }^{95}$

But if the military context is only subtly invoked as a factor in the Court's analysis of the power of the Secretary to enter into binding contracts (both generally, and specifically, as to termination settlement contracts), the importance of the military context is declared in ringing tones, with respect to the question of the legitimacy of a termination for convenience:

${ }^{95} I d$. at 322. A generation before Corliss Steam-Engine Co., in United States v. Tingey, 30 U.S. (5 Pet.) 115 (1831), the Supreme Court had decided that the United States has the inherent power to enter into contracts in order to carry out its constitutional responsibilities and its other powers, notwithstanding the absence of a textual grant of the authority to enter contracts in the Constitution and the absence of an express statutory grant of that power. That case, like Corliss Steam-Engine Co., arose out of a contract in a military setting- a fidelity bond that Lewis Deblois was required to post as a condition of his holding office as a Navy purser. The Court strongly affirmed that "the United States have such a capacity to enter into contracts," that authority being

an incident to the general right of sovereignty; and the United States being a body politic, may, within the sphere of the constitutional powers confided to it, and through the instrumentality of the proper department to which those powers are confided, enter into contracts not prohibited by law, and appropriate to the just exercise of those powers. ... To adopt a different principle, would be to deny the ordinary rights of sovereignty ....

30 U.S. (5 Pet.) 128. Unlike Corliss Steam-Engine Co., the Court's opinion in Tingey does not permit us to conclude that the military setting was critical to the outcome. Even so, however, because of the pre-eminence of military contracting in the activities of the United States in the early post-constitutional period, it is not accidental that the seminal case about the federal government's constitutional and statutory power to contract arose from a dispute about a mundane bond contract in a military context.

Although Tingey takes an expansive view of federal power in the area of contracting, extending that power beyond the literal limits of the applicable constitutional and statutory texts, it also could be said to reflect a significant and distinctive application of a congruence-oriented approach, rather than an exceptionalist approach. Specifically, the Court infers that the federal government possesses a power and capacity that ordinary natural persons enjoy: an inherent power to enter into contracts. In the constitutional setting of the case, the arguably germane "exceptional" distinguishing feature of the federal government was its status as a government of limited powers, expressly delegated. Tingey thus enhances federal government power by employing a formally congruence-oriented approach. 
Contracts for the armament and equipment of vessels of war may, and generally do, require numerous modifications in the progress of the work, where that work requires years for its completion. With the improvements constantly made in ship-building and steam-machinery and in arms, some parts originally contracted for may have to be abandoned, and other parts substituted; and it would be of serious detriment to the public service if the power of the head of the Navy Department did not extend to providing for all such possible contingencies by modification or suspension of the contracts, and settlement with the contractors. ${ }^{96}$

This is a forceful seminal statement of the factors that have made military procurement and the disputes and policy matters arising therefrom an engine for the development of exceptionalism in the law of federal government procurement in the United States. The legitimacy of the government's revising of its contractual commitments was considered obvious both because of the inherently uncertain changing fortunes of war, and because of the technically progressive nature of the production of military equipment. Indeed, the latter rationale appears to have entailed a pioneering judicial recognition of the special nature of what we might today call high technology procurement. In addition to these two factors that explain much of the recurring contribution of military procurement to the development of exceptionalist procurement law doctrine, a third reason for taking this highly exceptionalist approach is more subtly reflected in the Court's opinion, as well. That additional factor, also a recurring motif of the exceptionalist cases and doctrines arising from military procurement, is the important value of deferring to the expert judgment of those charged by law with making decisions regarding military matters. The Court explained that, the "completion of the machinery contracted for having become unnecessary from the termination of the war, the secretary, in the exercise of his judgment, under

\footnotetext{
${ }^{96} \mathrm{Id}$. at 323 .
} 
the advice of a board of naval officers, suspended the work." ${ }^{" 97}$ This early invocation of principles we might today call deferential review appears to have drawn part of its force from the Court's unquestioning assumption that it was especially unqualified to second-guess the assessment by the military officials as to the changed circumstances that they had determined were sufficient to warrant termination of the contract. ${ }^{98}$

Corliss Steam-Engine Co. thus testifies powerfully to the particularized impact of the military context of procurement on the development of exceptionalist doctrine. But this point is cast in more striking relief when we compare Corliss with the decision a mere 44 years later in United States v. Purcell Envelope Co. ${ }^{99}$ Purcell Envelope establishes, in effect, one of the leading congruence-influenced doctrines concerning federal government contract formation: that

\footnotetext{
${ }^{97} I d$. (emphasis added).
}

${ }^{98}$ Note that the influential decision in Decatur v. Paulding, 39 U.S. (14 Pet.) 497 (1840), reflects the powerful reluctance of the courts, in the nineteenth century, to allow judicial review even of ministerial administrative action. The Court declared emphatically:

The interference of the courts with the performance of the ordinary duties of the executive departments of the government would be productive of nothing but mischief; and we are quite satisfied that, that such a power was never intended to be given to them.

$I d$. at 516. The remarkable fact is that the executive action so zealously guarded against mischievous judicial review by the Decatur Court, was the failure to pay a widow's pension granted by statute, and judicial review did not appear in this context particularly likely to trench upon sensitive executive judgments. However, the case involved a claim to a military widow's pension; the claimant was in fact the widow of early American naval hero, Stephen Decatur. The Decatur Court's seemingly inexplicable overstatement of the dangers of opening the door to judicial review may well reflect the special reluctance to question executive judgments in contexts even weakly related to military concerns, that we see as well in the 1831 decision in Tingey and the 1875 decision in Corliss Steam-Engine.

${ }^{99} 249$ U.S. 313 (1919). 
a contractor's offer, coupled with an acceptance effectuated by a governmental official possessing the requisite authority results in a contract binding on the United States. ${ }^{100}$ The case arose when the Post Office Department solicited bids for a requirements contract to supply it with stamped envelopes for a four year term. Although the government had accepted Purcell's bid after having determined that it met applicable standards of responsibility, it subsequently attempted to revoke that acceptance and cancel the contract. The attempted revocation occurred after a new Postmaster General took office and in response to the unfavorable results of a reinvestigation of Purcell's financial soundness that had been ordered by the new Postmaster upon his assuming his office. In holding that the government was bound by its acceptance of Purcell's offer, the Court rejected the government's argument that the new Postmaster General had a "quasi-judicial" power "to review and set aside the decision of his predecessor, ${ }^{101}$ declaring that offer and acceptance yielded a binding contract:

We are unable to concede the fact or the power asserted to be dependent upon it. There must be a point of time at which discretion is exhausted. The procedure for the advertising for bids for supplies or services to the Government would else be a mockery - a procedure, we may say, that is not permissive but required ( $\$ 3709$, Rev. Stats.). By it the Government is given the benefit of the competition of the market and each bidder is given the chance for a bargain. It is a provision, therefore, in the interest of both Government and bidder, necessarily giving rights to both and placing obligations on both. And it is not out of place to say that the Government should be animated by a justice as anxious to consider the rights of the bidder as to insist upon its own. And, we repeat, there must be some point at which discretion ceases and obligation takes its place..... Upon the invitation, in accordance with law, of Postmaster General Gary, the Envelope Company and eleven others submitted bids. The Envelope Company was the lowest bidder and after the Company had been found upon investigation to be financially

\footnotetext{
${ }^{100} I d$. at 317-318, 319-320.

${ }^{101} I d$. at $318-319$.
} 
responsible its bid was accepted by entry of a formal order. ${ }^{102}$

The Purcell Court, in a routine civilian procurement, can find no reason to depart from the private law regime in which an acceptance of an offer yields a binding contract. Indeed, the Court lectures the government as to why the competitive mechanisms of government procurement make it all the more important that the government was bound by its acceptance. Thus Purcell reflects congruence, compounded with the "positive exceptionalism," previously noted, that imposes extra obligations on the government in favor of its contractors, especially in the contract formation process. ${ }^{103}$ In this routine civilian procurement contract setting, despite the adverse results of the new Postmaster General's intervening re-investigation of the contractor's financial standing and responsibility, the Court is unwilling or unable to recognize any legally sufficient basis for allowing, to allow the government the power to revise or avoid its contracts. $^{104}$

Although the contrast between any two cases may, of course, be misleading, or explained by other factors, the dramatically opposed approaches taken in Corliss Steam-Engine Co. and in Purcell Envelope is strong evidence of the distinctive impact of the military procurement context on the the development of exceptionalism in United States public procurement law.

\footnotetext{
${ }^{102} I d$.

${ }^{103}$ See TAN
}

${ }^{104}$ If the acceptance had not been effectuated by an official with actual authority to bind the United States, then exceptionalism would have come in to play in the form of the government's immunity from equitable estoppel, and the related rule that an exercise of apparent authority does not bind the United States. See supra note and accompanying text. 
The powerful impact of the military setting of the seminal termination for convenience case, explaining the expansive reception given to this assertion of authority there is further corroborated by the important opinion of the Court of Federal Claims in Torncello v. United States, ${ }^{105}$ noted previously. ${ }^{106}$ Judge Bennett's exhaustive opinion emphasizes that the termination for convenience doctrine was invented in the context of military procurement, was limited, for 75 years, to war-time military procurement, and was not applied to civilian procurement for almost a century. ${ }^{107}$ As Judge Bennett explained: "From the Corliss decision in 1876 to the last use of the World War II convenience termination clause in early 1944, the legal basis of the government's power had always been that the great and unpredictable circumstances of war necessitated some ability to halt useless contracts and settle with the contractors." 108

${ }^{105} 681$ F.2d 756 (1982). Although Torncello has been superseded as precedent by Krygoski Construction Co. v. United States, 94 F.3d 1537 (Fed. Cir. 1996), cert. denied, 520 U.S. 1210 (1997), Judge Bennett's opinion for the court in Torncello remains a uniquely careful record of the history of the development of the termination for convenience doctrine, and an important sign post as to its proper scope. It is also true that Judge Bennett's opinion for the 6 member court was substantially undermined, both by Judges Davis and Nichols, who concurred only in the judgment in Torncello, and by the separate opinion of Judge Friedman. Torncello, 681 F.2d at 773-774. As the Krygoski court subsequently noted (94 F.3d at 1541-1542 \& n.1), Judge Friedman's opinion, formally designated a concurring opinion, rather than one concurring only in the judgment, nonetheless reads more like the latter; on this basis the Krygoski court questioned whether Judge Bennett's opinion in Torncello may properly be considered a majority opinion for the court. Nevertheless, nothing in Krygoski impeaches Judge Bennett's historical account of the evolution of termination for convenience, which is its only relevance for present purposes. Indeed, Krygoski independently underscores the key role played by military procurement in the development of the termination for convenience doctrine. 94. F.3d at 15401541.

\footnotetext{
${ }^{106}$ See supra TAN

${ }^{107} 681$ F.2d at 764-765.

${ }^{108} I d$. at 766.
} 
Moreover, when the doctrine was expanded to apply to civilian and peacetime military procurement, it was allowed a more narrower scope. Despite the broader literal scope of contractual termination for convenience clauses, when "[w]ar was ... absent" from the situation, the Court of Claims "allow[ed] termination for convenience only when" there was some unforeseeable objective "change in the circumstances" that departed from the "expectations of the parties" to the contract. ${ }^{109}$ It is only with the 1996 decision of the Federal Circuit in Krygoski that a differential approach to termination for convenience in military and civilian cases appears to have been abandoned. ${ }^{110}$ Even today, under the deferential "abuse of discretion" test articulated in $\mathrm{Krygoski}^{l 11}$, it is likely that an abuse of discretion in instituting termination for convenience is less likely to be found in a military procurement case than in a civilian one. The policy considerations given in Corliss Steam-Engine Co. have retained their force: the changeability of the military needs on the demand side, the technical progressiveness of many of the objects of military procurement that drives changing specifications and needs on the supply side, and the understandable inclination of civilian judges to defer strongly to expert military judgments. As we shall see, these factors have application in many contexts outside the termination for convenience doctrine, driving the exceptionalist approach taken by the courts and policymakers.

${ }^{109} I d$. It is this requirement of an objective change in the circumstances that has been revised by the subsequent decision in Krygoski (see supra note ___ , which applies a more expansive formulation as to the proper availability of termination for convenience.

${ }^{110}$ See supra notes $83 \& 87$.

${ }^{111} 94$ F.3d at 1544. 


\section{The G.L. Christian Doctrine}

A second illustration of an exceptionalist doctrine that suggests the impact of military procurement on the development of the exceptionalist character in United States public procurement law is the G.L. Christian doctrine. ${ }^{112}$ As noted above, that doctrine teaches that standardized government contracts clauses that should have been included in a federal procurement contract under the applicable regulations, but which were omitted from the contract because of human error, should nonetheless be read into any contracts from which the language was mistakenly omitted. ${ }^{113}$ The clause that was mistakenly omitted in G.L. Christian, the seminal case, was, moreover, the required termination for convenience clause. The attempted termination for convenience was of a contract to construct a large military housing complex at Fort Polk, Louisiana. The termination was prompted by a decision to deactivate Fort Polk itself as a result of the reassessment of the nation's military needs and the best way in which to allocate limited resources to serve those needs. ${ }^{114}$ The Court was emphatic about the importance of the government's right of termination for convenience in the context of military contracts of this kind, and did not hesitate to conclude that the missing contractual clause should be read into the

\footnotetext{
${ }^{112}$ See supra TAN 24-25 and accompanying notes.

${ }^{113} I d$.

${ }^{114}$ G.L. Christian \& Assoc. v. United States, 312 F.2d 418, 419 (Ct. Cl. 1963), cert.
} denied, 382 U.S. 821 (1965). 
contract. ${ }^{115}$ The rationale for the court's decision, set out in the margin, fairly shouts out the critical role played by the military procurement context. Moreover, the court was equally clear

\footnotetext{
${ }^{115}$ The Court of Claims explained in considerable detail (312 F.2d at 426-427; citations and footnote omitted):
}

We are not, and should not be, slow to find the standard termination article incorporated, as a matter of law, into plaintiff's contract .... The termination clause limits profit to work actually done, and prohibits the recovery of anticipated but unearned profits. That limitation is a deeply ingrained strand of public procurement policy. Regularly since World War I, it has been a major government principle, in times of stress or increased military procurement, to provide for the cancellation of defense contracts when they are no longer needed, as well as for the reimbursement of costs actually incurred before cancellation, plus a reasonable profit on that work -- but not to allow anticipated profits. In World War I, there was the Act of June 15, 1917. 40 Stat. 182, and the Dent Act of 1919, 40 Stat. 1272, both of which were held to prevent awards of prospective or possible profits. In World War II, the termination provisions used by the war contracting agencies (at least since late 1941) uniformly disallowed anticipated profits. The same policy against unearned profits was embodied in the Contract Settlement Act (Act of July 1, 1944, 58 Stat. 649), Section 6(d)(5) of which directed war contracting agencies, in settling terminated contracts, to award "such allowance for profit on the preparations made and work done for terminated portions of the war contract as is reasonable under the circumstances"; the regulation issued by the Office of Contract Settlement specifically limited profit to preparations made and work done (32 C.F.R., 1944 Supp., Sec. 8006.3(c), p. 3065). Similarly, the Lucas Act of August 7, 1946, 60 Stat. 902, authorizing the departments and agencies "to consider, adjust, and settle equitable claims of contractors," limited the amount of the claim to "losses (not including diminution of anticipated profits) incurred ***." Since World War II, the standard termination clauses promulgated by the Defense Department and its constituent agencies have taken the same tack. Literally thousands of defense contracts and subcontracts have been settled on that basis in the past decades.

This history shows, in our view, that the Defense Department and the Congress would be loath to sanction a large contract which did not provide for power to terminate and at the same time proscribe anticipated profits if termination did occur. Particularly in the field of military housing, tied as it is to changes and uncertainties in installations, would it be necessary to take account of a possible termination in advance of completion, and to guard against a common law measure of recovery which had been disallowed for so many years in military procurement. 
that the military context established that it was reasonable to charge the contractor with knowledge of the government's conventional right to terminate for convenience, because of its status as an "experienced contractor" on projects of this kind. ${ }^{116}$ Today the G..L. Christian doctrine is regarded as a bright-line rule applicable to all federal government procurement contracts. ${ }^{117}$ But there can be little doubt that the military procurement context played at least the role of midwife-if not the role of father or mother- in the birth of this rule. This then is a case in which a case arising out of military procurement and the special policies applicable thereto catalyzed the emergence of an exceptionalist doctrine that was given application even outside its original military procurement context. ${ }^{118}$

\section{The Sovereign Acts and Unmistakability Doctrines}

The development of the Sovereign Acts Doctrine provides a third, albeit subtler, illustration of the influence of disputes and cases arising out of military procurement on the emergence of a powerful exceptionalist norm in United States public procurement law. ${ }^{119}$ The present author has previously written at considerable length, describing the evolution of that

${ }^{116} I d$. at 427 .

${ }^{117}$ Schwartz, Procurement Law CASES AND materials, supra note 5, at $\{123\}$.

${ }^{118}$ It does not appear that limitation of the doctrine to the military procurement context was ever seriously urged or considered. But this does not undercut the argument made here; rather it demonstrates the degree to which military procurement cases have formed the template for the development of generic public procurement law doctrine in the United States.

${ }^{119}$ See supra notes $27-29$ and accompanying text. 
doctrine and only the highlights need be rehearsed here. ${ }^{120}$ Briefly, the sovereign acts doctrine operates to excuse the government of the United States from breach of contract liability where "public and general" acts undertaken in the performance of its sovereign responsibilities might otherwise constitute a breach of contract. Cases decided under the doctrine include ones where the government has acted in a manner that burdens or magnifies the contractual obligations of the government's contracting partner, the contractor. ${ }^{121}$ But they also include cases in which the government has acted directly to repudiate its own promise of performance. ${ }^{122}$

The Sovereign Acts Doctrine's operation often can be understood as that of a canon of interpretation for government contracts. ${ }^{123}$ So viewed, it is a canon that dictates that neither the government's express undertakings nor its implied obligations to cooperate with its contractors should be construed to make promises so unconditional that they are not subject to being superseded by public and general governmental actions that might, of necessity, have the incidental effect of undercutting the contract. Read as a canon of contractual interpretation, this presumption is subject to being overcome by contractual language that is sufficiently clear and

\footnotetext{
${ }^{120}$ See Schwartz, Liability for Sovereign Acts, supra note 1, passim. See especially, id.. at 651-674.

${ }^{121}$ E.g. Deming v. United States, 1 Ct. Cl. 190 (1865), appeal dismissed, 76 U.S. (9 Wall.) 145 (1870); Jones v. United States, 1 Ct. Cl. 383 (1865).

${ }^{122}$ Horowitz v. United States, 267 U.S. 458 (1925).

${ }^{123}$ Schwartz, Procurement Law Cases and Materials, supra note 5, at $\{175-176\}$; Schwartz, Assembling Winstar , supra note 1, at
} 
unmistakable to override the presumption. ${ }^{124}$ So viewed, the sovereign acts doctrine may best be understood as a canon of avoidance that enables a court to avoid the conclusion that the government's sovereign duties and its contractual undertakings have come into irreconcilable conflict. ${ }^{125}$ On the other hand, in some contexts and in some applications the doctrine cannot easily be understood as a canon of construction of the government's bargain, and may better be viewed as simply excusing what would otherwise be a culpable breach. ${ }^{126}$ Without recapitulating all of the nuances of this doctrine and its development, it is worthwhile here to note some key features of the two cases (Deming and Jones) in which the doctrine was devised by the United States Court of Claims, predecessor to today's Court of Federal Claims, and the Horowitz decision, in which the Supreme Court subsequently put its imprimatur on the doctrine. The facts of these cases show that the court were more readily able to understand the need to protect sovereign authority against contractual infringement in these cases because of the military procurement context and related contexts that made protection of sovereign authority a particularly compelling value in the cases. Once again, the special strength of sovereign

\footnotetext{
${ }^{124}$ Schwartz, Assembling Winstar, supra note 1, at ___ ; Schwartz, Wake of Winstar, supra note 1 at

${ }^{125}$ This formulation of the sovereign acts doctrine as a rebuttable canon of construction to be used in interpreting government contracts the performance of which is adversely impacted by subsequent public and general acts of the government, highlights the near identity of purpose and effect between this doctrine and he historically distinct unmistakability and reserved powers doctrines. The present author has discussed this overlap in Liability for Sovereign Acts, supra note 1, at __, and the Supreme Court's unwillingness to recognize this overlap in Assembling Winstar, supra note 1, at , and in Wake of Winstar, supra note 1 at

${ }^{126}$ Schwartz, Assembling Winstar, supra note 1, at _ ; Schwartz, Wake of Winstar. supra note 1, at __ ; Schwartz, Procurement Law Cases AND Materials, supra note 5, at $\{175-176\}$.
} 
prerogatives in contexts related to military needs and decision-making, and the reluctance of the courts to second guess authorized military decision-makers was a powerful influence on the outcome. On the other hand, these cases also show that the courts recognized that strong protection of sovereign power included, but was not limited to, the context of military procurement. There were other contexts in which the claims of sovereignty were regarded as comparably strong, or nearly so. Still, a balanced assessment of the legacy of these cases will show the strong impact of military procurement in engendering the flexible jurisprudence of our exceptionalist body of public procurement law. Moreover, we shall see that recent cases in which the Supreme Court at least arguably has taken a somewhat more restrictive approach to the Sovereign Acts Doctrine and/or the related Unmistakbility Doctrine have arisen in civilian and regulatory contracting contexts which, the Court perceived there to be no comparably compelling need to protect the exercise of sovereign authority. So here military procurement and protection of military decision-makers plainly assisted at the birth of the exceptionalist doctrines, which then carried over to other, non-military contexts. However, the vigor with which these exceptionalist doctrines are applied is today somewhat less when the strongest claims and prerogatives of sovereignty are not threatened- outside the military procurement context.

In 1865, in its very first Term and in the first volume of its official reporter, the newly established United States Court of Claims decided Deming v. United States, ${ }^{127}$ and Jones v. United States, ${ }^{128}$ the pair of seminal cases. Note the date, at the end of the United States' Civil

\footnotetext{
${ }^{127} 1$ Ct. Cl. 190 (1865), appeal dismissed, 76 U.S. (9 Wall.) 145 (1870).

${ }^{128} 1$ Ct. Cl. 383 (1865).
} 
War.

The first of these cases, Deming, arose from a series of contracts to provide rations for the Marine Corps during the first few years of the Civil War. The contractor made a claim in the newly available Court of Claims asserting that the government had breached these contracts, initially by imposing certain tariff duties on imports that increased the price to the contractor of acquiring the rations the contractor was obligated to provide. An additional breach was claimed to result from the enactment of the Legal Tender Act of $1862,{ }^{129}$ which provided for the issuance of paper United States currency that was valid for the payment of obligations though not backed by a reserve of gold. ${ }^{130}$ The contractor asserted that this second legislative act likewise had the effect of increasing its cost of performing its contractual obligations. The Court of Claims rejected the contractor's assertion that "by these enactments the United States have changed, and in effect imposed new conditions upon the peformance of their contracts."131 Because the government was engaged in "exercising its sovereign power of providing laws for the welfare of the State," and because "[t]he statute[s] "bear[] upon [the government's contract] as [they] bears upon all similar contracts between citizens, and affect[s] it in no other way," the enactment of the statutes could not be considered a breach of the government's contractual undertaking. ${ }^{132}$

The court's explanation of its holding is laconic to a fault, and no clear indication is given

${ }^{129} 12$ Stat. 345.

${ }^{130}$ The enactment of the Legal Tender Act was made necessary by the exigencies and the expenses of the Civil War. See Knox v. Lee, 79 U.S. 457, (1870).

${ }^{131}$ Deming, 1 Ct. Cl. at 190.

${ }^{132}$ Id. at 191 . 
Centrality of U.S. Military Procurement (Draft 10/17/04), page 73

as to the reach of the principle that is invoked, leaving many important questions unresolved for future cases. ${ }^{133}$ Accordingly, although the particular contract involved in this seminal case was a military procurement contract, it is impossible to discern with any certainty whether that was important to the outcome reached. What is unmistakably clear is the court's utter confidence that "general enactments of Congress" are not to be "construed as evasions of [a] particular contract." ${ }^{\prime 34}$ And it seems fair to report that, in this terse opinion, marginally greater emphasis is laid upon the threat that the claim presents to the "sovereign right of enacting laws," than on any other factor. ${ }^{135}$ In other words, the contractor's claim that its contract had indirectly been violated threatened to trench upon a core exercise of sovereign authority: the legislative power of Congress. Surely this warranted the exceptionalist doctrine that resulted. Yet the fact remains that Deming was a case of military procurement, which spawned what became a far-reaching assertion of exceptional prerogatives for the government. Deming's defense of a "sovereign right of enacting laws" that cannot be forfeited by the conduct of the government's contracting is assuredly a defense of the key prerogatives of sovereignty. ${ }^{136}$ But the court's conclusion that the "United States as contractor are not responsible for the United States as lawgiver" simultaneously serves to vindicate the importance of the contracting function. ${ }^{137}$

\footnotetext{
${ }^{133}$ See Schwartz, Liability for Sovereign Acts, supra note 1, at 653-665 (exploring the ambiguities and unresolved issues).

${ }^{134}$ Deming, $1 \mathrm{Ct} . \mathrm{Cl}$. at 191.

${ }^{135} I d$. at 191 .

${ }^{136} I d$. at 191.

${ }^{137} I d$. at 191 .
} 
Centrality of U.S. Military Procurement (Draft 10/17/04), page 74

The underlying message of Deming, the seminal case, thus is that enforceable government procurement contracts and the integrity of sovereign power must be made to co-exist, because both are of first-rank importance. They are made to co-exist by a doctrine that strongly discourages interpretation of a government procurement contract as promising that government contracts will not be adversely affected by the enactment of intervening generically applicable statutes. The extent to which Deming served as a vindication of the government's contracting function is most apparent if one considers the probable consequences that would have followed had the court reached the opposite decision in Deming and similar cases. Failure to embrace the sovereign acts doctrine principle invented in Deming would have presented the government with a dilemma. The government could risk being significantly restricted in its regulatory and legislative authority once it had entered into a web of contracts that could not (without contractual liability) be burdened or impaired by such general legislation. Alternatively, the government would have to forego the substantial benefits of being able to secure goods and services available through the market. It is plain, at least from our vantage point of hindsight, that neither option would have been tolerable. Moreover, although no single case can suffice to prove this point, it is suggested that the importance of reconciling the government contracting function with the exercise of its sovereign regulatory powers gained much of its plausibility and appeal, from the outset, from the military subject matter of the contracts involved in Deming. Moreover, the strong association between the government procurement function and the military context was inescapable giving the timing of the contracts and the litigation over them, in the time of the Civil War. The performance of military procurement contracts such as those at issue 
Centrality of U.S. Military Procurement (Draft 10/17/04), page 75

in Deming was both innately important, and inherently susceptible of running afoul of the enactment of such generic legislation as the tariff and currency statutes that gave rise to the claims in that case.

If Deming suggests that assertion of sovereign prerogatives is supported by, but not limited to the military procurement context, Jones, the successor case, more clearly demonstrates the impact of military procurement and exigencies in fostering exceptionalism. In Jones it was not the contracts that were military, technically, but the governmental "interference" that allegedly burdened the contractor's performance was caused by military operations and military decisions that the court was loathe to second guess. The claim in Jones arose out of a contract to with the Commissioner of Indian Affairs to survey certain lands described in treaties between the United States and certain Indian nations. Understood in historical context, this may, in fact, be properly regarded as a contract closely tied to military operations. More striking, however, is that the plaintiff's claim was that their required contractual performance for the government had been rendered more difficult and expensive by the actions of the government. What actions? Plaintiff claimed that by withdrawing army troops from certain particular military posts in Indian country, in asserted violation of the treaties involved, the United States had rendered more difficult and expensive the performance of its contractual undertaking. ${ }^{138}$ The Court of Claims responded sharply to what it plainly took to be the plaintiff's hubris, explaining: "Whatever acts the government may do, be they legislative or executive, so long as they be public and general, cannot be deemed specially to alter, modify, obstruct or violate the particular contracts into
${ }^{138} 1 \mathrm{Ct} . \mathrm{Cl}$. at 384. 
which it enters with private persons."139 The Court plainly sought to, and did, articulate a generic principle to shield the United State from claims of this kind, which would subordinate sovereignty to an inflated and unrealistic version of contractual undertakings, expressed and implied. Still it seems fair to conclude that the fact pattern impressed upon the court the need for such protection. The Court surely would have considered the plaintiff's invitation judicially to review the decisions of the United States concerning stationing of troops and authorizing troop movements, made in the course of the Indian Wars, to be unthinkable. Again the military context made clear the importance of protecting sovereignty, generically. But the military context also made especially plain the inappropriateness of the sought-for exercise of judicial review and the intrusive impact on government decision-making that would have resulted from entertaining this claim.

The impact of military considerations, if not military procurement per se, on the acceptance of the exceptionalist principles of the Sovereign Acts Doctrine was underscored further when the Supreme Court of the United States endorsed and indeed broadened the application of the sovereign acts doctrine in Horowitz v. United States. ${ }^{140}$ If Deming and Jones (like Corliss Steam-Engine Co.) were products of the Civil War and the Indian Wars, Horowitz was an artifact of World War I and its aftermath. A federal agency, the Ordnance Salvage Board, had in 1919 contracted to sell the plaintiff certain silk in the government's possession that evidently had become surplus, in the wake of the end of the war. Although the agency

$$
\begin{aligned}
& { }^{139} \mathrm{Id} . \\
& { }^{140} 267 \text { U.S. } 458 \text { (1925). }
\end{aligned}
$$


contractually promised to ship the surplus silk with a day or two of receipt of the purchaser's order, it was unable to do so when the shipping instructions were received. Timely performance was blocked by an embargo on non-essential shipments imposed by another federal agency, the United States Railroad Administration. The plaintiff sought damages for the loss that it incurred when shipping was thus delayed and it was unable to resell the silk at the high price prevailing at the time of the order to ship the silk that had been dishonored by the government. ${ }^{141}$ Although the decision went beyond the circumstances of Deming and Jones in that the government had dishonored its own promise, rather than simply burdening the exercise of the contractor's undertakings, the Horowitz court simply invoked Deming and Jones as controlling. ${ }^{142}$ Although the Court does not specifically cite any military necessity for the regulatory rail embargo, or for the sale of surplus military property itself, the significance of the military context is suggested by the facts. As in Deming it appears a balanced conclusion to state here simply that recognition of the sovereign prerogative (to regulate use of the rails in the public or national interest) was dramatically illustrated by the factual context. Military procurement (or surplus equipment sales) served simply to illustrate effectively the importance of shielding the exercise of the sovereign authority from restrictions implied from a government commercial undertaking.

The sovereign act doctrine cases should be read to teach that the courts' embrace of exceptionalist rules of government contracting was advanced by the context of military procurement or surplus equipment sale. And where entertaining a contractual claims would

\footnotetext{
${ }^{141} I d$. at $458-461$.

${ }^{142} I d$. at 461 .
} 
Centrality of U.S. Military Procurement (Draft 10/17/04), page 78

have entailed judicially reviewing the justification for a military decision, the court have been particularly forthcoming about protecting sovereign prerogatives against restraints on the exercise of sovereign authority that otherwise might be inferred from the operation of the government's contractual undertakings. But the protection of sovereign authority surely was not limited to the context of military procurement or interference through judicial review with military decisionmaking.

In recent years, as the Supreme Court arguably has cut back somewhat on the breadth or vigor of this exceptionalist shield for the exercise of government sovereignty. ${ }^{143}$ The author has argued against any conclusion that Winstar or its progeny have significantly reduced the scope or vigor of the Sovereign Acts Doctrine and the related Unmistakability Doctrine. ${ }^{144}$ But even if that is adjuged otherwise, these cases arise in a civilian contexts and typically involve the use of contracts as a primary or a supplemental means of regulating private economic activity. ${ }^{145}$ It is plain that the courts deciding these cases did not perceive that important sovereign prerogatives were at stake in these cases; the contexts were markedly different from the military procurement settings, and related contexts in which sovereignty has been perceived as vitally threatened by the courts. Accordingly, the strength of exceptionalist policies may have waned when the strong implications for sovereignty typically recognized in military procurement contexts - and in some

${ }^{143}$ See, United States v. Winstar, 518 U.S. 839 (1996); $f$. Mobil Oil co. v. United States, U.S. _ $(199 \mathrm{x})$ (endorsing norm of congruence but noting that the Government had abandoned arguments invoking the Sovereign Acts doctrine). See sources cited at notes 28 \& 29.

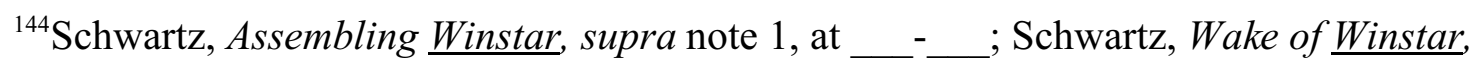
supra note 1, passim.

${ }^{145}$ See cases cited and discussed in Schwartz, Wake of Winstar, supra note 1, passim. 
other contexts in which strong contractual rights would have threatened key prerogatives of sovereignty- were absent.

\section{The deferential standard of review in judicial bid protests}

Another compelling illustration of the contribution of military procurement contexts to exceptionalism in the United States law of government contracts can be seen in the cases and statutes that embody the deferential standard of review applicable to bid protest cases. This deferential standard was discussed above, in connection with the Steinthalcase, involving bid protest jurisdiction in the United States District Courts. ${ }^{146}$ Steinthal itself arose out of procurement for parachutes by the Air Force. ${ }^{147}$ And the policies articulated by the court as reasons for the deferential standard of review reflect the very policy considerations that typically drive the exceptionalist doctrines noted in this Article: the technical nature of the procurement policy issues, the technical complexity of the relevant body of law, and the superior expertise of procurement officials and the General Accounting Office that all called for deference to the agency's judgment. ${ }^{148}$ In subsequent years this deferential standard, was codified, and is codification gave explicit recognition to the special need for extra deference in the military procurement context. The statutory standard of review for judicial bid protests now provides in pertinent part: "In exercising [bid protest] jurisdiction under this subsection, the courts shall give

\footnotetext{
${ }^{146}$ See supra TAN 57 - 59 and accompanying notes.

${ }^{147} 455$ F.2d 1289 (D.C. Cir. 1971)

${ }^{148}$ Id. at 1298-1299, 1300-1306. Accord: Shoals American Industries, Inc. v. United
} States, 877 F.2d 883, 888-889 (11 $1^{\text {th }}$ Cir. 1989). 
due regard to the interests of national defense and national security and the need for expeditious resolution of the action." ${ }^{149}$ The dramatic impact of military procurement in shaping an exceptionalist body of law could not be more explicit. Still, equally telling is the fact that the deferential standard of review for judicial bid protest cases, as it was interpreted in Steinthal, a military procurement case, was carried over to civilian procurement, and was also codified, thus spreading the impact of the exceptionalism flowing from the military template for the United States' procurement law regime. ${ }^{150}$

\section{Other Examples of Military-Derived Exceptionalism}

Part II of this paper introduces a host of additional examples of exceptionalism that are fairly clearly traceable to the impact of military procurement. Were space no object, each of these could be explored in detail. But the examples explored more carefully above should be entirely sufficient to establish the theory advocated here: that the centrality of military procurement in the development of the United States' procurement law regime was a powerful engine for the development of the exceptionalist approach so evident in that regime. Still, it is appropriate briefly to list here other exceptionalist doctrines whose content and development appear to reflect the impact of military procurement:

${ }^{149} 28$ U.S.C. $\S 1491(b)(3)$.

${ }^{150} 28$ U.S.C. $\S 1491(b)(4)$, invoking the Administrative Procedure Act, 5 U.S.C. $§ 706$. See supra note 57. 
- the doctrine of strict compliance; ${ }^{151}$

- the government's right to terminate for default where no performance deadline has yet been missed, simply because ultimate performance has been endangered;

- the broad authority of federal government contracting officers to impose unilateral change orders that substantial increase, reduce or alter the contractor's obligations of performance under a federal government contract; ${ }^{152}$

- the development of competitive negotiation procedures as an alternative to sealed bidding as a means of securing full and open competition, the importance of which is most evident in military procurement settings; ${ }^{153}$ and

- the development of cost-reimbursement contracting as an alternative to firm-fixed price contracts because the need to shift the risk of uncertainty as to the cost of performance to

${ }^{151}$ See supra note 18 and accompanying text. Note that Arrow Lacquer, cited there, arose from military procurement. The facts of that case arguably suggest an abuse of discretion by the government in a context in it appears at first blush that a non-material performance defect could not possibly have had any significance. But performance disputes tribunals undoubtedly and understandably are loathe in the extreme ever to be put in the position of deciding whether a performance failure in a military context is material.

${ }^{152}$ See supra TAN 13 and authorities cited therein. The policies that underlie the broad termination for convenience doctrine developed in the context of military procurement are equally applicable here. See TAN notes 95-98 and accompanying notes. Indeed, analytically, a termination for convenience is just an extreme unilateral change; and a partial termination for convenience is indistinguishable from a change order. Accordingly, it is not surprising that the policies that lie behind these two exceptionalist doctrines are essentially identical. Corliss SteamEngine Co. explains precisely why military procurement contracts are especially likely to give rise to change orders. See supra TAN 96.

${ }^{153}$ See supra TAN 56-57. The need for criteria other than lowest price to judge which offer affords best value to the government is most readily apparent in cases of military procurement. Presumably no one wants our government to be forced to buy the cheapest fighter plane as opposed to the fastest, most maneuverable, or stealthiest plane. 
the government is greatest in connection with contracts for cutting edge performances that push the envelope of available technology. ${ }^{154}$

We close with one final example of exceptionalism that is explicitly and clearly tied to the context of military procurement: the "government contractor defense" recognized in Boyle $v$. United TechnologiesCorp. ${ }^{155}$ As indicated above, the emergence of that exceptionalist doctrine is explicitly tied by the Court to the considerations applicable to its military procurement context. ${ }^{156}$

\section{Conclusions, Recommendations for Further Study and Policy Prescriptions}

This Article has undertaken to define more rigorously the phenomenon of exceptionalism in public procurement law, and to study the incidence of this phenomenon in the federal government contracts law of the United States. It has also sought an explanation for the strong exceptionalist tendency found in United States public contract law, particularly in the law of government contract performance. It has also examined the prominent role - especially noteworthy when viewed through the lens of comparative public procurement law - that military procurement has played in the development of the legal regime for public procurement in the United States. And it has tested the explanation that including military procurement at the

\footnotetext{
${ }^{154}$ See TAN 62 and authorities collected in note 62.

${ }^{155} 487$ U.S. 500 (1988).

${ }^{156}$ See TAN 59-63.
} 
center of the public procurement system in the United States has been a major cause of the emergence of this exceptionalist character in the government contracts law of the United States. Although the reader will have to draw her own conclusions as to the strength of the evidence marshaled here, the two basic theses of this Article were supported by the historical and doctrinal survey and analysis that is offered here.

First, the incidence of exceptionalism is dramatically skewed when United States public procurement law is viewed as a whole; it is highly concentrated in the doctrines that govern public contract performance and associated disputes. United States law of public contract formation is, instead, mostly a blend of 1) reverse exceptionalism that imposes special duties on federal agencies engaged in procurement that exceed any counterpart doctrines applicable to private parties purchasing goods or services in the commercial marketplace, and 2) significant elements of congruence, as to which the requirements of public contract formation parallel or approximate those borne by private contracting parties. ${ }^{157}$ Although there are certainly significant exceptionalist doctrines that affect federal government contract formation, and yet others that affect both formation and performance, or which transcend these categories, the main thrust of exceptionalism is concentrated in the law of public contract performance in the United States.

This pattern that describes the incidence of exceptionalism in United States public contract law has particular significance for comparative law purposes. The law of government contract performance is not treated as a co-equal part of the public procurement law, along with

\footnotetext{
${ }^{157}$ See supra note __ for a listing of significant elements of congruence in public contract formation law in the United States..
} 
the law of government contract formation, in many other nations, including significant European procurement law regimes. Accordingly, recognizing the concentration of exceptionalism in the United States' law of public contract performance, and the divergence of this body of law from the norms of other countries is an essential precondition to accomplishing meaningful and illuminating comparative law analysis in the field of public procurement law.

Second, the evidence appears to support the conclusion that the central role played by military procurement in the development of the United States public procurement regime is a primary explanation for the strongly exceptionalist character that has emerged in that system. Many of the key exceptionalist doctrines emerged in cases involving military procurement. And the rationales given for the exceptionalist approaches taken generally confirm that the military context significantly influenced the exceptionalist doctrines that emerged in these cases.

Among the significant policies factors that have contributed to the exceptionalist character of this body of law is the unusual susceptibility of military procurement contracts to unforeseen circumstances because of the shifting fortunes and inherent unpredictabiliy of war. A second recurring factor is the susceptibility of military procurement contracts to unforeseen changes because of the technological sophistication and progressiveness of the goods and services subject to procurement. It is striking that this feature of military procurement was recognized, quite early on in United States history, in Corliss Steam-Engine Co., the seminal case on the termination for convenience power of federal agencies engaged in procurement, which arose from the termination of contracts caused by the end of the Civil War. A third factor of very substantial consequence is the highly understandable but nonetheless striking reluctance of 
Centrality of U.S. Military Procurement (Draft 10/17/04), page 85

federal courts closely to review the decisions of military officials as to the military necessity for particular goods or services or changes in the specifications or contract modifications or terminations.

These factors are displayed recurrently in the leading procurement cases, and plainly provide a major explanation for the exceptionalist approach taken to military procurement in the United States. Moreover, because military procurement served as a template for the development of the entire system of public procurement law in the United States, the exceptionalist model and accompanying policies that were developed and initially justified for military purposes have now been carried over, to a very substantial degree, though not fully, into the law regulating civilian contracts of the United States. Indeed, in most instances and in most respects, this is a single unified body of law today.

What this pattern most strongly suggests is that early in the political and legal history of the United States, and early in the development of the United States public procurement law regime, the compelling nature of the sovereign prerogatives of government was first and most thoroughly recognized in the context of disputes arising out of military procurement. Although this recognition has not carried over with undiminished force to the civilian context, military procurement has served, to a significant degree, as a Trojan horse, that opened the procurement law regime to exceptionalist doctrines that accommodate the special needs and responsibilities borne by the government, even when it enters into the procurement market place.

This causal explanation proposed here is further corroborated by examining instances in which congruence has played a more prominent role in United States public procurement law. 
Such cases are characteristically ones in which the compelling policy justifications for exceptionalist approaches that have been recognized in cases involving military procurement were simply lacking because of the absence of a military context for the procurement. As Purcell Envelope demonstrates, this differential approach is of long standing. On the other hand, as noted above, because military procurement-based doctrines have now crossed over to apply in non-military procurement settings, and a largely unified body of procurement law has been fostered by federal statutes and regulations, the disparity has disappeared in many contexts. Nonetheless, it may not be entirely gone. For instance, the Supreme Court has in recent years shifted to a somewhat more congruence-oriented posture regarding federal government contracts, especially with respect to the Sovereign Acts and Unmistakability Doctrines. ${ }^{158}$ The civilian and regulatory context of the contracts involved in such cases is markedly different than that of the cases that produced these paradigmatic exceptionalist doctrines and that disparity in context likely explains the Court's recent drift in the direction of congruence in these cases. Moreover, because of the unification of regulation of federal public contracts in the post-World War II era, there is a risk that this more congruence-oriented approach will be carried over, inappropriately perhaps, to contexts in which sovereign prerogatives deserve more protection and demand exceptionalist treatment. These may in fact include military procurement cases. On the other hand, although it is far too soon to render any firm judgments on these matters, the terrorist attacks on the United States of 9/11/2001, as well as the Iraq War and ensuing occupation of 2003-2004, have created opportunities to re-dramatize the important prerogatives of sovereignty

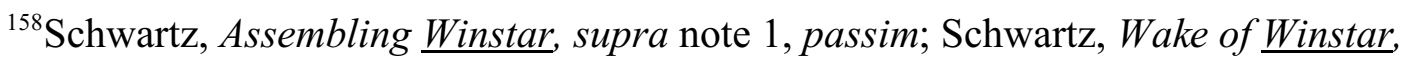
supra note 1, passim.
} 
that are implicated by public contracting. Although this is largely a subject for another article, contract disputes and procurement policy controversies emerging from the Iraq War and subsequent occupation have highlighted both the grounds for, and the potential abuses associated with, exceptionalism in the law of federal public contracting.

This Article has also identified important opportunities for further research in a comparative law vein, designed to explore further and test in other contexts the theses presented here. Of particular importance would be studies that employ the constructs of exceptionalism and congruence employed here to explore the development of public procurement law in a variety of other nations, including developing nations, and those with transitional economies emerging from a legacy of socialism that are developing or seeking to develop competitive, transparent public procurement law regimes. Such comparative law work would also offer an important opportunity to test the second thesis of this Article: that the military procurement template that was the basis for much of the development of the United States public procurement law regime has been a primary cause of the strong exceptionalist strain in the public procurement law of the United States. ${ }^{159}$

${ }^{159}$ As noted above, note ___ this study does not examine the body of state (or local) public procurement law that is in force in the various States of the United States. Because state and local governments do not have military functions, an extension of the exceptionalism and congruence constructs to the study of state and local public procurement law in the United States also has potential to shed additional light on the strength of the argument made here concerning the impact of military procurement on the exceptionalist character of United States public procurement law.

Such additional study would necessarily be time consuming because of the formal independence of each of the States' public procurement regimes and the possible diversity of practices among the states in this regard. But such additional study would be particularly valuable as it would help to ferret out the presence, or absence, of other factors unique to the United States legal context, that might explain divergence of United States federal public 
Finally, the argument advanced here has important implications for public policy regarding the design of public procurement regimes world wide. In particular, it has lessons for developing nations and transitional economies first seeking to develop an open, competitive, and transparent public procurement law system. The author has sought, in previous work, as well as in this Article above, to identify the important advantages that exceptionalist doctrines of public procurement law, especially in the law of government contract performance, confer on a nation and its procurement system. ${ }^{160}$ The responsibilities and duties of the sovereign indeed compel us to devise a body of public contract law that balances the special needs of the government with the protection of the expectations and interests of government contractors. Because the military procurement context has served to highlight these considerations, as it served as the template for the development of the procurement regime in the United States, it cast that system in an exceptionalist mold. The author concludes that the impact on the development of the procurement law regime in the United States has been a beneficial one, fostering doctrines that engendered a desirable and appropriate flexibility for the sovereign engaged in procurement,

contract law from tendencies that are dominant elsewhere in the world.

If state and local public procurement law in the United States generally lacks the exceptionalist character of federal public procurement law, that would provide additional evidence to support the argument made here. On the other hand, if it were to emerge that state and local public procurement law in the United States tends to share fully the exceptionalist character of the federal model, the question that would then have to be addressed is whether this similarity reflects a) the influence of the federal model on development of state and local procurement law in the United States, or b) the presence of other factors (not addressed in this study) in the United States legal environment that predispose United States public procurement law systems to the exceptionalist approach.

${ }^{160}$ Schwartz, Liability for Sovereign Acts, supra note 1, passim; Schwartz, Assembling Winstar, supra note 1, passim; Schwartz, Wake of Winstar, supra note 1, passim. 
while finding appropriate devices to protect the key interests of government contractors and would-be contractors.

Military procurement has performed this important catalytic role in the development of exceptionalist public procurement law doctrine in the United States. Nonetheless, concerns about security, flexibility, and nationalistic/protectionist interests have discouraged many nations developing their own procurement law regimes in recent times from regulating military and security-related public procurement under the umbrella of an open, competitive and transparent procurement law regime. The same is true of the major international instruments that attempt to establish regional or world open public procurement markets, such as the European Union treaties and Directives and the Government Procurement Agreement of the World Trade Organization. Nevertheless, if military procurement played so important a role in catalyzing the emergence of an appropriately exceptionalist public procurement law regime in the United States, as is claimed here, there may be substantial adverse consequences when military procurement is not engrossed emerging national and international public procurement regulatory regimes. In light of the findings of this Article, these hidden spillover costs of excluding most military procurement from the reach of developing and established public procurement regulatory regimes should no longer be overlooked. The widespread acceptance of such commonlyaccepted exclusions should be reconsidered. 